Article

\title{
Evaluation of the Summer Overheating Phenomenon in Reinforced Concrete and Cross Laminated Timber Residential Buildings in the Cold and Severe Cold Regions of China
}

\author{
Haibo Guo 1,2,*(D), Lu Huang 1,2, Wenjie Song ${ }^{1,2}$, Xinyue Wang ${ }^{1,2}$, Hongnan Wang ${ }^{1,2}$ \\ and Xinning Zhao ${ }^{1,2}$ \\ 1 School of Architecture, Harbin Institute of Technology, Harbin 150001, China; \\ 19S134163@stu.hit.edu.cn (L.H.); 18S034014@stu.hit.edu.cn (W.S.); 18S034002@stu.hit.edu.cn (X.W.); \\ 20S034016@stu.hit.edu.cn (H.W.); 20S134166@stu.hit.cn (X.Z.) \\ 2 Key Laboratory of Cold Region Urban and Rural Human Settlement Environment Science and Technology, \\ Ministry of Industry and Information Technology, Harbin 150001, China \\ * Correspondence: guohb@hit.edu.cn
}

Received: 8 November 2020; Accepted: 26 November 2020; Published: 29 November 2020

\begin{abstract}
As the climate changed in recent years, an increase in summer indoor temperatures in severe cold and cold regions of China has started to affect thermal comfort. However, the local design standard for energy efficiency does not recognize this phenomenon. This paper reports the potential overheating phenomenon in residential buildings and examines the rationale for the current thermal designs adopted in severe cold and cold regions of China. In this study, the two most commonly used building materials, reinforced concrete (RC) and cross laminated timber (CLT), are used separately in the design of an 18-story residential building envelope located in six different cities in the severe cold and cold regions. The energy consumption and indoor operative temperatures during the operation of these buildings are simulated using Integrated Environmental Solutions Virtual Environment (IES VE). The results demonstrate that both the RC and the CLT buildings experience varying degrees of overheating in any climate subregion. The CLT buildings have longer overheating hours compared to the RC buildings, especially in the cold regions. The results also indicate that for apartments on higher stories, the cooling energy consumption and indoor temperature also increase gradually. The research results suggest that the local design standard for energy efficiency needs to be adjusted by adding thermal design methods for summer to reduce the periods of overheating.
\end{abstract}

Keywords: overheating phenomenon; cross laminated timber (CLT); energy consumption; operative temperature; residential buildings

\section{Introduction}

\subsection{Climate Change and Northeast China}

Climate change is one of the great challenges the world is facing today. In 2019, the average temperature across global land and ocean surfaces was $14.85^{\circ} \mathrm{C}$, an increase of $0.95{ }^{\circ} \mathrm{C}$ over the twentieth century, making 2019 the second warmest year on record. It is estimated that the average temperature could increase by 1.1 to $5.4^{\circ} \mathrm{C}$ in 2100 according to a report by the National Oceanic and Atmospheric Administration (NOAA) [1]. The Intergovernmental Panel on Climate Change (IPCC) also announced that land regions should experience more severe increases than the ocean regions, and indicated that the warming trend in the northern hemisphere was more significant from 2006-2015 
than from 1850-1990, and this trend is more obvious at higher latitudes [2]. Climate change raises the temperature of the northern hemisphere in summer, and China is located in this hemisphere, thus facing the same challenge [3], especially in Northeast China (Figure 1). There is growing evidence of overheating risk in warm weather in buildings in temperate climate regions [4]. Overheating has been observed in many countries in the northern hemisphere [4-9]. Overheating affects the health of occupants, with a particular bearing on the quality of sleep that leads to reduced productivity [10-12]. In some extreme cases, heat stress caused by overheating can result in death, particularly in some vulnerable groups [4]. Over 2000 people died in the UK during the 10-day European heatwave in 2003 [13]. It is predicted that the number of deaths related to overheating could triple by 2050 [14].

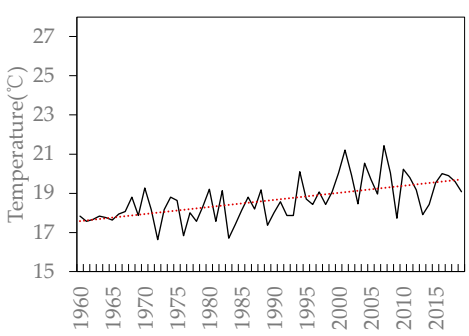

(a) Hailar

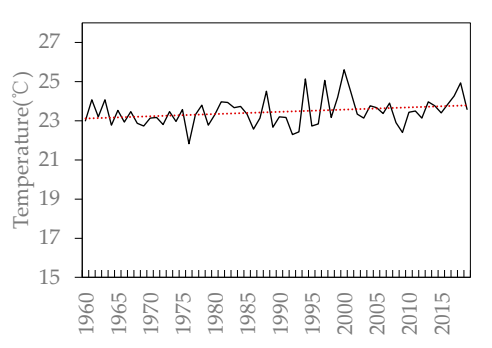

(d) Shenyang

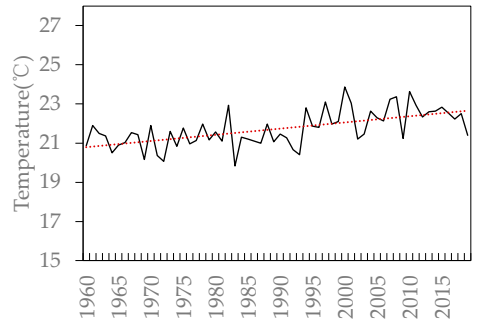

(b) Harbin

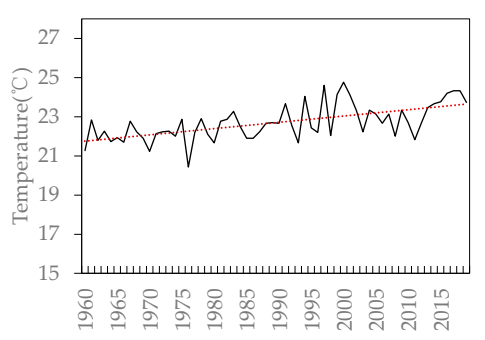

(e) Dalian

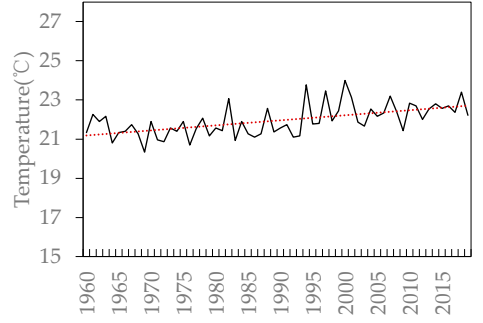

(c) Changchun

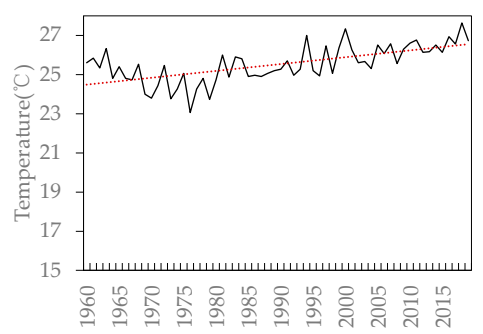

(f) Beijing

Figure 1. Average summer temperature of major cities in Northeast China (June to August). (Data source: China Meteorological Data Service Center, National Meteorological Information Center, drawn by the authors).

\subsection{Global Overheating Building Standards}

At present, there is no internationally accepted definition of overheating, and different countries have developed their own criterion for the assessment of overheating. The Chartered Institution of Building Services Engineers (CIBSE) produced the CIBSE TM36 standard for climate change and the indoor environment. Here, the criterion for overheating in dwellings is of temperatures above $28{ }^{\circ} \mathrm{C}$ in living areas for more than $1 \%$ of occupied hours and above $25^{\circ} \mathrm{C}$ in bedrooms for more than $1 \%$ of occupied hours [15]. In subsequent standards, CIBSE TM52 points out the operative temperature of predominantly mechanically ventilated rooms in summer should not exceed $26{ }^{\circ} \mathrm{C}$, and higher temperatures should not occur for more than $3 \%$ of the occupied time [16]. CIBSE TM59 specifies that the operative temperature in bedrooms between 10:00 p.m. and 7:00 a.m. should not exceed $26^{\circ} \mathrm{C}$, and higher temperatures should not occur for more than $1 \%$ of the annual hours in predominantly naturally ventilated dwellings [17]. The ANSI/ASHRAE Standard 55-2017 developed by the American Society of Heating, Refrigerating, and Air Conditioning Engineers (ASHRAE) indicates the acceptable operative temperature ranges for naturally conditioned spaces [18]. In European Standard EN 15251, the maximum indoor temperature for residential mechanically cooled buildings is $26^{\circ} \mathrm{C}$. The standard also regulates the operative temperature range for the comfort zone in residential buildings without mechanical cooling systems, and indicates that the use of fans can increase the upper limits by a few degrees depending on the air velocity generated by the fan [19]. A discussion paper titled "Next steps 
in defining overheating from zero carbon hub $(\mathrm{ZCH})^{\prime \prime}$ recommends that bedrooms should not be designed to experience temperatures above $26^{\circ} \mathrm{C}$ for more than a specified percentage ( $1 \%$ ) of occupied hours [20]. The Passive House Planning Package (PHPP) software released by the Passive House Institute defines $25^{\circ} \mathrm{C}$ is the limit for overheating, classifying the outcome as catastrophic if higher temperatures are experienced for over $15 \%$ of the time and as poor in the case of 10 to $15 \%$ of the time [21]. Indoor operative temperature has been adopted in many specifications as the criteria for assessment of the overheating risk. In addition, the operative temperature is obtained by combining both the air temperature and the mean radiant temperature, which is deemed to be an effective way to describe the actual experience of the people [20]. The thermal comfort and overheating criteria are summarized and presented in Figure 2.

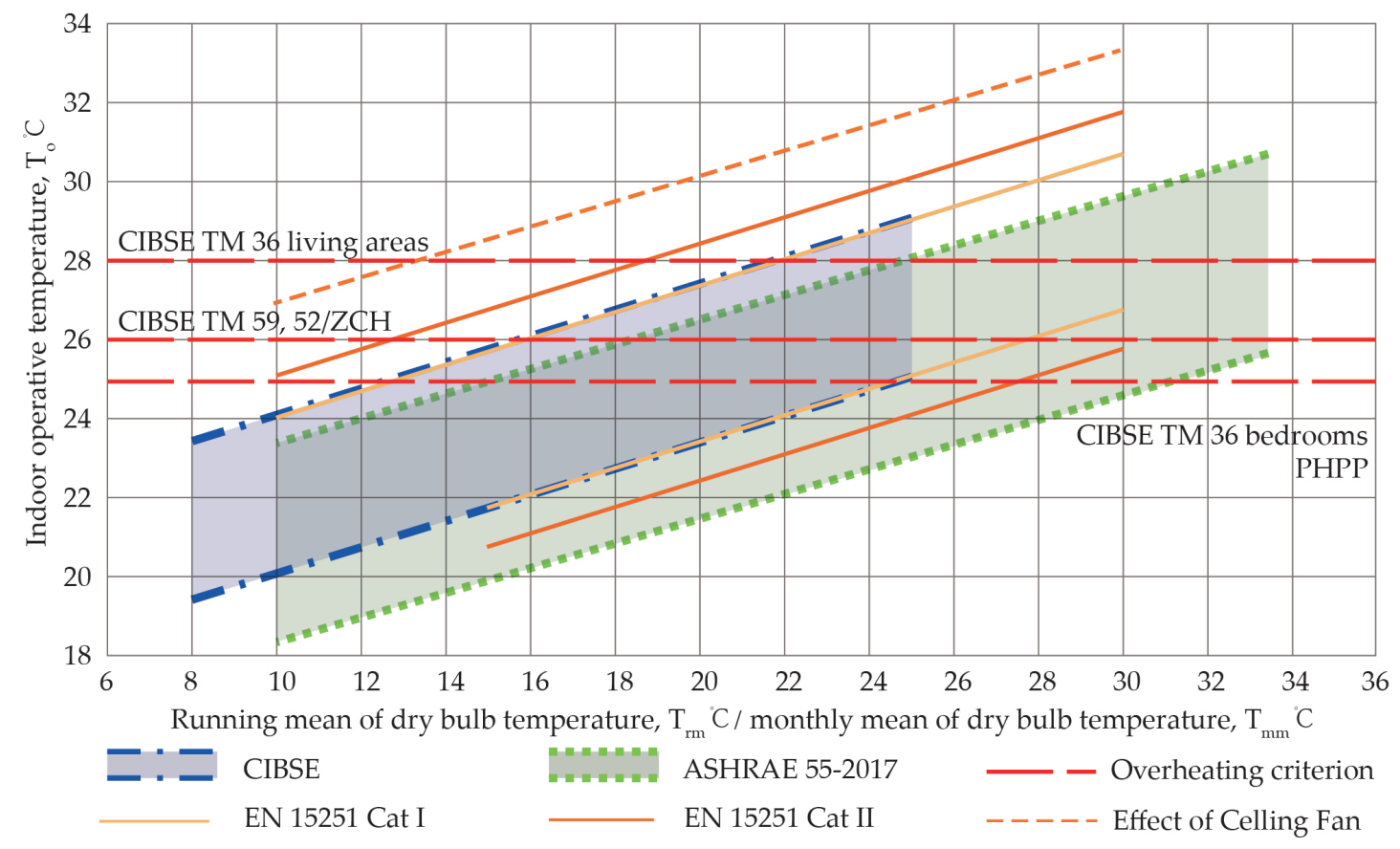

Figure 2. Thermal comfort and overheating criteria. (Data source: CIBSE TM36 (Chartered Institution of Building Services Engineers Technical Memorandum), CIBSE TM52, CIBSE TM59, ASHRAE 55-2017 (American Society of Heating, Refrigerating and Air-Conditioning Engineers), EN 15251 (European Standards), Passive House Planning Package (PHPP), and Zero Carbon Hub (ZCH); drawn by the authors).

\subsection{National Standard for Energy Saving Design of Residential Buildings in Severe Cold and Cold Areas of China}

China is divided into several distinct climate zones due to its vast territory. According to the Code for Thermal Design of Civil Buildings (GB 50176-2016), there are five climate regions in China: severe cold, cold, temperate, hot summer and cold winter, and hot summer and warm winter. According to the number of cooling degree days based on $26^{\circ} \mathrm{C}$ and heating degree days based on $18^{\circ} \mathrm{C}$, the severe cold and cold regions can be subdivided into five regions: "severe cold region $1 \mathrm{~A}$, " "severe cold region $1 \mathrm{~B}$, ," "severe cold region 1C," "cold region 2A," and "cold region 2B" [22]. In clause 4.1 of the general provisions in the Design Standard for Energy Efficiency of Residential Buildings in Severe Cold and Cold zones (JGJ 26-2018) [23], it clearly stipulates that windproof design should be considered for the entrance and exit to buildings in regions $1 \mathrm{~A}, 1 \mathrm{~B}, 1 \mathrm{C}$, and $2 \mathrm{~A}$ in winter, and ventilation in summer should be considered for region $2 \mathrm{~B}$. Furthermore, clause 4.2 for thermal design of the structural envelope specifies that windows on the south (including balcony glazing) of buildings in region $2 \mathrm{~B}$ should be provided with horizontal shading, whilst windows on the east and west façade should be provided with movable sunshades. However, the code only specifies the heating insulation design for region 
$2 \mathrm{~B}$ in summer, and there are no clear criteria or design methods to mitigate the overheating problem in the summer, such as using shading designs for the solar gain prevention, phase change materials (PCM), or movable insulation layers for the other regions in the severe cold and cold regions.

\subsection{Studies on Overheating in Biobased and RC Buildings}

Biobased materials and reinforced concrete (RC) are the two main classifications of building materials used in China. RC is currently the most popular structural material, and the proportion of the urban and rural residential buildings using concrete and cement was $95.8 \%$ in 2018 [24]. However, as a biobased material, timber has thousands of years of application in China, and the importance of using timber has been recognized by the government [25]. In addition, there are abundant forest resources in the severe cold and cold regions, and woodland accounts for $40.9 \%$ of the land area [26]. CLT commonly consists of an uneven number of timber panel layers $(3,5$, or 7$)$. Each timber panel is placed side-by-side in a $90^{\circ}$ arrangement [27]. CLT has good physical and mechanical properties and the use of this building material can lower carbon emissions and save energy in cold climates [28,29]. Research has shown that $\mathrm{RC}$ and timber structures incur the risk of overheating due to the rising temperatures [30]. Willand et al. [8] tested the temperatures and energy efficiency rating of living rooms in the summer in 107 homes in Australia. They highlighted that $20 \%$ of the living rooms tested maximum indoor temperatures exceeding $33^{\circ} \mathrm{C}$. Mavrogianni et al. [31] investigated indoor overheating assessments of 101 London dwellings in summer 2009 using temperature monitoring, a questionnaire survey, and simulation. Results indicated overheating phenomenon occurred in the majority of the living rooms and bedrooms surveyed. Sharifi et al. [32] investigated the summer indoor operative temperatures of apartments built in Adelaide by the year 2010. They clarified the overheating period during the summer months and pointed out that the daily air temperature of the top floor was above $32{ }^{\circ} \mathrm{C}$. Appropriately one-fifth of the total summer hours were overheated. Adekunle et al. [30] focused on summer overheating and occupant comfort in two prefabricated timber houses in southeast England and found that $67 \%$ of the rooms had extreme overheating in summer, according to the CIBSE comfort model during the monitoring period, stating that the risk of overheating with timber construction is higher than that of more heavyweight construction on account of the lack of thermal mass in prefabricated timber. Pajek et al. [33] compared the surface temperature of lightweight construction (timber-framed) (LWC) and heavyweight construction (reinforced concrete) (HWC), and found that it was $1.3^{\circ} \mathrm{C}$ higher for lightweight buildings, with the main reason being the relatively low thermal mass of LWC, approximately 2.4 times lower than heavyweight construction. Hudobivnik et al. [34] investigated the nonstationary thermal performance of different multilayer external walls in LWC and HWC under typical summer conditions in Slovenia and found that LWC resulted in higher indoor air temperatures than $\mathrm{RC}$, brick, and stone, on the order of $3.5^{\circ} \mathrm{C}, 3{ }^{\circ} \mathrm{C}$, and $3.3^{\circ} \mathrm{C}$ respectively. Kuczynski et al. [35] compared the influence of lightweight and heavyweight wall construction on summer thermal performance in conditions of persistent and prolonged heat waves in temperate climates and measured occurrences of maximum internal air temperature above $28^{\circ} \mathrm{C}$ for as many as 18.6 days in an exceptionally warm August. Nebia et al. [36] aimed to predict and assess the impact of floor level, thermal mass, ventilation strategy, and orientation on overheating risk and daylighting levels, and determined that the number of hours above the overheating benchmark increased from the bottom to the top floors. Research related to overheating phenomenon is tabulated in Table 1. 
Table 1. Summary of results from overheating investigations in residential buildings.

\begin{tabular}{|c|c|c|c|c|}
\hline Research Regions & Buildings & Assessment Scheme & Findings & References \\
\hline Australia & $\begin{array}{l}107 \text { homes with lightweight } \\
\text { insulated external walls }\end{array}$ & $\begin{array}{l}\text { 3-day-averaged daily mean } \\
\text { outdoor and living } \\
\text { room temperature }\end{array}$ & $\begin{array}{l}\text { The temperature in 6-star rated apartments } \\
\text { was higher in summer than the lower } \\
\text { rated homes. } \\
\text { The thickness of insulation is closely related } \\
\text { to the indoor temperatures in the summer, } \\
\text { risk of heat stress and cooling loads in a mild } \\
\text { temperate climate. }\end{array}$ & [8] \\
\hline UK & 101 household spaces & $\begin{array}{c}\text { CIBSE Guide A, } 2007 \text { (number } \\
\text { of occupied hours with living } \\
\text { rooms and bedrooms above } \\
28^{\circ} \mathrm{C} \text { and } 26^{\circ} \mathrm{C} \text { ) }\end{array}$ & $\begin{array}{l}\text { Homes particularly bedrooms are already at } \\
\text { risk of overheating during high temperature } \\
\text { in the current climate. }\end{array}$ & [31] \\
\hline Australia & $\begin{array}{l}11 \text { energy-efficient } \\
\text { multilevel houses }\end{array}$ & $\begin{array}{l}\text { The upper threshold of adaptive } \\
\text { thermal comfort in ASHRAE } 55\end{array}$ & $\begin{array}{l}\text { The maximum temperature of the top floor } \\
\text { was above } 32{ }^{\circ} \mathrm{C} \text { for one-fifth of the total } \\
\text { summer days with the condition of space } \\
\text { cooling and natural ventilation. }\end{array}$ & [32] \\
\hline UK & 2 prefabricated timber buildings & $\begin{array}{l}\text { CIBSE (hours above } 28^{\circ} \mathrm{C} \text { for } \\
\text { living rooms and } 26^{\circ} \mathrm{C} \text { for } \\
\text { bedrooms) and } \\
\text { BSEN15251(hours above } \\
\text { Cat II upper) }\end{array}$ & $\begin{array}{l}\text { Extreme summertime overheating in } 67 \% \text { of } \\
\text { the spaces during the monitoring period. }\end{array}$ & {$[30]$} \\
\hline Finland, Austria, and Spain & $\begin{array}{l}3 \text { buildings in } \\
\text { timber-framed construction }\end{array}$ & $\begin{array}{l}\text { Thermal response } \\
\text { of construction }\end{array}$ & $\begin{array}{l}\text { Enhanced lightweight envelopes would } \\
\text { improve thermal comfort in lightweight } \\
\text { buildings and reduce the cooing energy. }\end{array}$ & [33] \\
\hline
\end{tabular}


Table 1. Cont.

\begin{tabular}{|c|c|c|c|c|}
\hline Research Regions & Buildings & Assessment Scheme & Findings & References \\
\hline Central Europe & $\begin{array}{c}\text { Building envelopes in light } \\
\text { weight construction (LWC) and } \\
\text { heavy weight } \\
\text { construction (HWC) }\end{array}$ & Indoor air temperature & $\begin{array}{l}\text { Due to the difference of thermal mass and } \\
\text { positioning of thermal insulation. obvious } \\
\text { difference in thermal behavior was found } \\
\text { between light weight and heavy } \\
\text { weight envelopes. }\end{array}$ & [34] \\
\hline Poland & $\begin{array}{l}2 \text { detached energy efficient } \\
\text { single-family buildings in } \\
\text { traditional masonry } \\
\text { construction and lightweight } \\
\text { skeletal frame }\end{array}$ & $\begin{array}{l}\text { Air temperature and energy } \\
\text { demand for cooling based on set } \\
\text { point temperatures of } \\
25^{\circ} \mathrm{C} \text { and } 26^{\circ} \mathrm{C}\end{array}$ & $\begin{array}{l}\text { The use of cellular concrete walls instead of } \\
\text { lightweight timber frame walls can be very } \\
\text { effective in reducing the maximum and } \\
\text { average daily indoor temperatures during } \\
\text { hot summers in temperate climates. }\end{array}$ & [35] \\
\hline UK & $\begin{array}{l}\text { A typical high-rise } \\
\text { residential building }\end{array}$ & $\begin{array}{l}\text { CIBSE (internal temperatures } \\
\text { exceed } 28^{\circ} \mathrm{C} \text { and } 26^{\circ} \mathrm{C} \text { in living } \\
\text { rooms and bedrooms for more } \\
\text { than } 1 \% \text { of the occupied hours) }\end{array}$ & $\begin{array}{l}\text { The floor position is considered to be an } \\
\text { important factor. The overheating hours } \\
\text { increase with the height of the apartment. }\end{array}$ & [36] \\
\hline
\end{tabular}

Data source: summarized by the authors from the references. 
There are few studies on the phenomenon of overheating in the severe cold and cold regions in China, since the focus has been on the thermal environment in winter. As shown in Table 2, in northern China, Su et al. [37] analyzed thermal comfort in old residential buildings in summer and found that the average temperatures in north- and south-facing bedrooms were 32.1 and $33.2^{\circ} \mathrm{C}$, respectively, and that discomfort was experienced without mechanical cooling in August. Yan et al. [38] investigated human thermal comfort in residential buildings in cold areas in summer in a study of 72 residential buildings in Yinchuan, and the results showed that the neutral temperature was $4.2^{\circ} \mathrm{C}$ higher than the preferred temperature. The subjects in the cold region are poorly adapted to higher temperatures; the neutral temperature and the upper limit of acceptable temperature are lower than the indoor thermal comfort standards for free-running buildings in China. Yang et al. [39] studied the indoor environment and thermal comfort in residential buildings in Baotou, China, and indicated that the neutral temperature in summer was higher than the expected temperature, implying that residents preferred lower indoor temperatures. Mao et al. [40] studied the indoor thermal environment in residential buildings in cold regions in summer using a questionnaire survey and temperature monitoring, and suggested that residents were dissatisfied with the indoor thermal environment, although they were tolerant to higher temperatures due to the restriction of natural ventilation and economic conditions. Wang et al. [41] used an air temperature transducer to find that the frequency of indoor air temperatures above $26.5^{\circ} \mathrm{C}$ exceeded 56\%. Yang et al. [42] studied the thermal comfort of occupants in a mix of air conditioned (AC) and no air conditioned buildings and found that the mean operative temperature of residential buildings reached $29.3^{\circ} \mathrm{C}$ in summer. Song [43] investigated 43 families in Tianjin and found that only $7 \%$ of the sample fell within the range of $22^{\circ} \mathrm{C}$ to $26^{\circ} \mathrm{C}$ specified in the design code for heating ventilation and air conditioning of civil buildings (2012), and most indoor temperatures were between $27^{\circ} \mathrm{C}$ and $31^{\circ} \mathrm{C}$ in summer.

Table 2. Summary of results from thermal comfort investigations in residential buildings in China.

\begin{tabular}{|c|c|c|c|c|}
\hline Research Regions & Climate & Buildings & Indoor Average Temperature & References \\
\hline Dalian & Cold 2A & $\begin{array}{l}2 \text { residential buildings } \\
\text { in brick }\end{array}$ & $\begin{array}{l}\text { Natural ventilation }(\mathrm{NC}) \text { south and } \\
\text { north bedroom: } 33.2^{\circ} \mathrm{C}, 32.1^{\circ} \mathrm{C} \text {. } \\
\text { Air conditioned (AC) south and } \\
\text { north bedroom: } 29.1^{\circ} \mathrm{C} ; 32.5^{\circ} \mathrm{C}\end{array}$ & [37] \\
\hline Yinchuan & Cold 2A & 72 apartments & $28.9^{\circ} \mathrm{C}$ & [38] \\
\hline 5 provinces & Cold $2 \mathrm{~A}$ and $2 \mathrm{~B}$ & 100 apartments & $29.3^{\circ} \mathrm{C}$ & [40] \\
\hline Tianjin & Cold 2B & 43 apartments & $97 \%$ between $27^{\circ} \mathrm{C}$ and $31^{\circ} \mathrm{C}$ & [43] \\
\hline Jiaozuo & Cold & 34 apartments & $29.5^{\circ} \mathrm{C}$ & [42] \\
\hline Harbin & Severe cold 1B & $\begin{array}{l}257 \text { apartments in six } \\
\text { residential communities }\end{array}$ & $26.9^{\circ} \mathrm{C}$ & [41] \\
\hline Baotou & Severe cold & $\begin{array}{l}\text { residential buildings } \\
\text { in brick }\end{array}$ & $28^{\circ} \mathrm{C}$ & [39] \\
\hline
\end{tabular}

Data source: summarized by the authors from the references.

\subsection{Study Objective}

The aforementioned context raises several questions. The current national standard released in 2018 claims that it is unnecessary for residential buildings located in the severe cold and cold regions to mitigate overheating in the summer, such as using external shading devices. Hence, there are few studies on the potential summer overheating in residential buildings in the cold and severe cold regions of China. Furthermore, as a sustainable building material, CLT has already been proved to be effective for reducing energy consumption in the winter. The performance of this material in the summer remains unclear.

This paper considers the operative temperature in summer for RC and CLT residential buildings and addresses the following questions: (1) How serious is the potential overheating phenomenon in summer in the severe cold and cold regions in China? (2) Do the higher floors of residential buildings 
have lower energy efficiency than the floors below? (3) Do CLT buildings have lower cooling energy consumption than RC buildings in the summer season?

\section{Methods and Data}

\subsection{Framework of the Study}

The area of this work centered on building cooling energy consumption and indoor operative temperatures in summer during the operational phase. The study is divided into the following steps (Figure 3). First, six representative cities were selected from the severe cold subregion (1A, 1B, 1C) and cold subregions $(2 \mathrm{~A}, 2 \mathrm{~B})$ as the simulation environment. Second, an 18-story reinforced concrete apartment with 72 apartments that had already been established in Harbin city was adopted as the case study building. Third, building energy consumption and the indoor operative temperature in summer was simulated with the commercial software IES VE. During the entire simulation process, the following factors were examined as keynotes:

(1) Building materials. The energy efficiency of both RC and CLT buildings were simulated and compared during the simulation.

(2) Cooling loads and indoor temperatures.

(3) Relationship between indoor temperature and height.

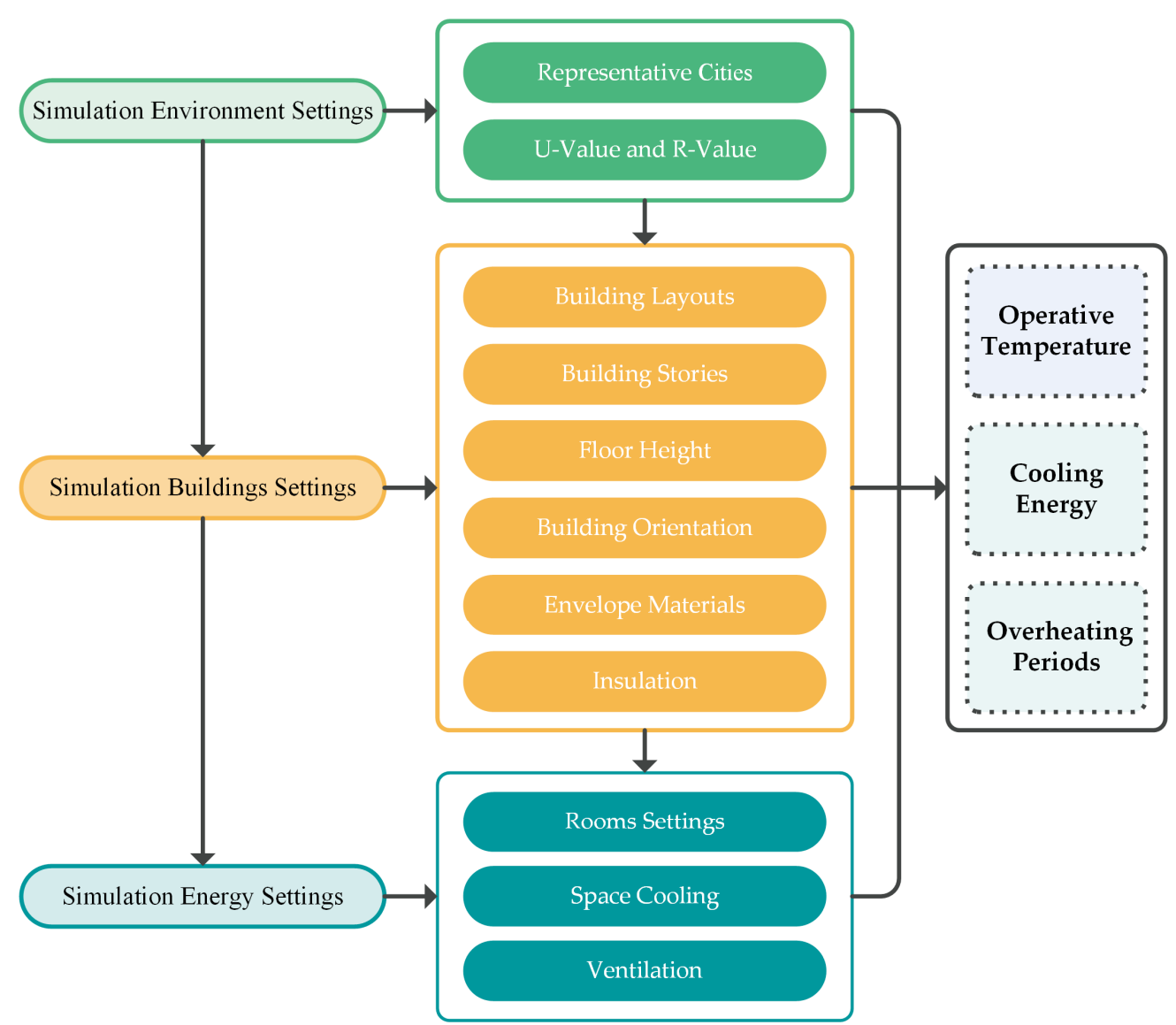

Figure 3. Flowchart of the building simulation. (Data source: drawn by the authors).

\subsection{Simulation Environment}

In this study, the six climate representative major cities from the severe cold and cold regions selected are Hailar, Harbin, Changchun, Shenyang, Dalian, and Beijing. The U-value and R-value of 
the roof, walls, windows, and ground are strictly limited in design codes in order to ensure the thermal insulation of these buildings at low temperatures. The locations and the thermal design details of the six cities are presented in Table 3 and Figure 4.

Table 3. Six case study cities by climate regions in China.

\begin{tabular}{|c|c|c|c|c|c|c|}
\hline \multirow{2}{*}{ Climate Region } & \multirow{2}{*}{ Subregion } & \multicolumn{2}{|c|}{ Main Indicators } & \multirow{2}{*}{$\begin{array}{l}\text { Representative } \\
\text { City }\end{array}$} & \multirow{2}{*}{$\begin{array}{l}\text { U-Value (Local } \\
\text { Regulations) }\end{array}$} & \multirow{2}{*}{$\begin{array}{l}\text { R-Value (Loca } \\
\text { Regulations) }\end{array}$} \\
\hline & & Temperature & HDD/CDD & & & \\
\hline \multirow{3}{*}{ Severe cold } & Severe cold 1A & \multirow{3}{*}{$\begin{array}{c}\mathrm{T}_{\min \cdot \mathrm{m}} \leq-10^{\circ} \mathrm{C} \\
145 \leq \mathrm{d}_{\leq 5}\end{array}$} & $6000 \leq \mathrm{HDD} 18$ & Hailar & $\begin{array}{c}\text { Roof: } \leq 0.25 \\
\text { Wall: } \leq 0.50 \\
\text { Window: } \leq 2.20\end{array}$ & $\begin{array}{c}\text { Ground Floor: } \\
\geq 1.10\end{array}$ \\
\hline & Severe cold 1B & & $\begin{array}{c}5000 \leq \text { HDD } 18 \\
<6000\end{array}$ & Harbin & $\begin{array}{c}\text { Roof: } \leq 0.30 \\
\text { Wall: } \leq 0.55 \\
\text { Window: } \leq 2.20\end{array}$ & $\begin{array}{c}\text { Ground Floor: } \\
\quad \geq 0.83\end{array}$ \\
\hline & Severe cold $1 C$ & & $\begin{array}{c}3800 \leq \text { HDD } 18 \\
<5000\end{array}$ & $\begin{array}{l}\text { Shenyang; } \\
\text { Changchun }\end{array}$ & $\begin{array}{c}\text { Roof: } \leq 0.40 \\
\text { Wall: } \leq 0.60 \\
\text { Window: } \leq 2.20\end{array}$ & $\begin{array}{c}\text { Ground Floor: } \\
\geq 0.56\end{array}$ \\
\hline \multirow{2}{*}{ Cold } & Cold 2A & \multirow{2}{*}{$\begin{array}{c}-10{ }^{\circ} \mathrm{C}<\mathrm{T}_{\min \cdot \mathrm{m}} \\
\leq 0{ }^{\circ} \mathrm{C} \\
90 \leq \mathrm{d}_{\leq 5}<145\end{array}$} & $\begin{array}{c}2000 \leq \text { HDD } 18 \\
<3800 \\
\text { CDD26 } \leq 90\end{array}$ & Dalian & $\begin{array}{c}\text { Roof: } \leq 0.45 \\
\text { Wall: } \leq 0.70 \\
\text { Window: } \leq 2.80\end{array}$ & - \\
\hline & Cold 2B & & $\begin{array}{c}2000 \leq \text { HDD } 18 \\
<3800 \\
\text { CDD26 }>90\end{array}$ & Beijing & $\begin{array}{c}\text { Roof: } \leq 0.45 \\
\text { Wall: } \leq 0.70 \\
\text { Window: } \leq 2.80\end{array}$ & - \\
\hline
\end{tabular}

Data source: Code for thermal design of civil buildings (GB 50176-2016), Design standard for energy efficiency of residential buildings in severe cold and cold zones (JGJ 26-2010). CDD26: air conditioning degree days based on $26{ }^{\circ} \mathrm{C}$; HDD18: heating degree days based on $18{ }^{\circ} \mathrm{C}$; $\mathrm{d}_{\leq 5}$. days of daily average temperature $\leq 5^{\circ} \mathrm{C}$; $\mathrm{T}_{\min \cdot \mathrm{m}}$ : average temperature of the coldest month.

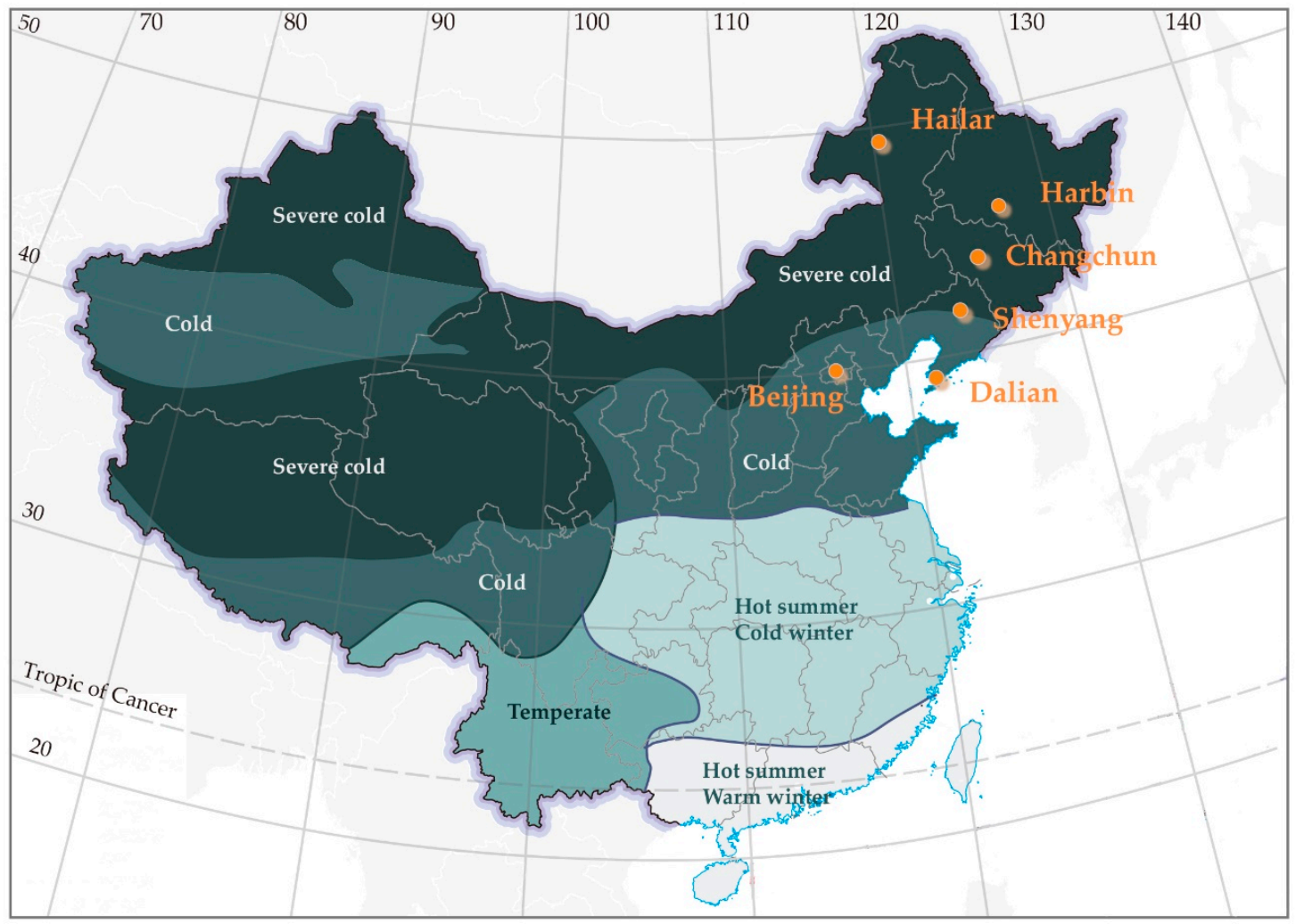

Figure 4. Locations of the six case study cities in Mainland of China. (Data source: Code for thermal design of civil buildings (GB 50176-2016); drawn by the authors). 


\subsection{Details of the Simulation Buildings}

\subsubsection{The RC Building}

The 18-story RC building in Harbin chosen as the case study building is a typical design in the severe cold and the cold regions. There are two units with similar plans on each floor. Each unit is made up of two apartments, each with a living room and two bedrooms with different orientations. For the simulation in other cities, the specification of the building envelope was adjusted for the different thermal zones to meet the requirements of the local codes. The details of the architectural design are presented in Tables 4 and 5 and Figure 5.

Table 4. Building information.

\begin{tabular}{cc}
\hline Items & Values \\
\hline Floor Area $\left(\mathrm{m}^{2}\right)$ & 7683.44 \\
External Wall Area $\left(\mathrm{m}^{2}\right)$ & 5826.24 \\
Timber Volumes $\left(\mathrm{m}^{3}\right)$ & $24,099.26$ \\
Building Heights $(\mathrm{m})$ & 50.4 \\
Number of Layers & 18 \\
Story Height $(\mathrm{m})$ & 2.8 \\
\hline
\end{tabular}

Table 5. External wall and roof designs for the RC residential buildings in the six cities.

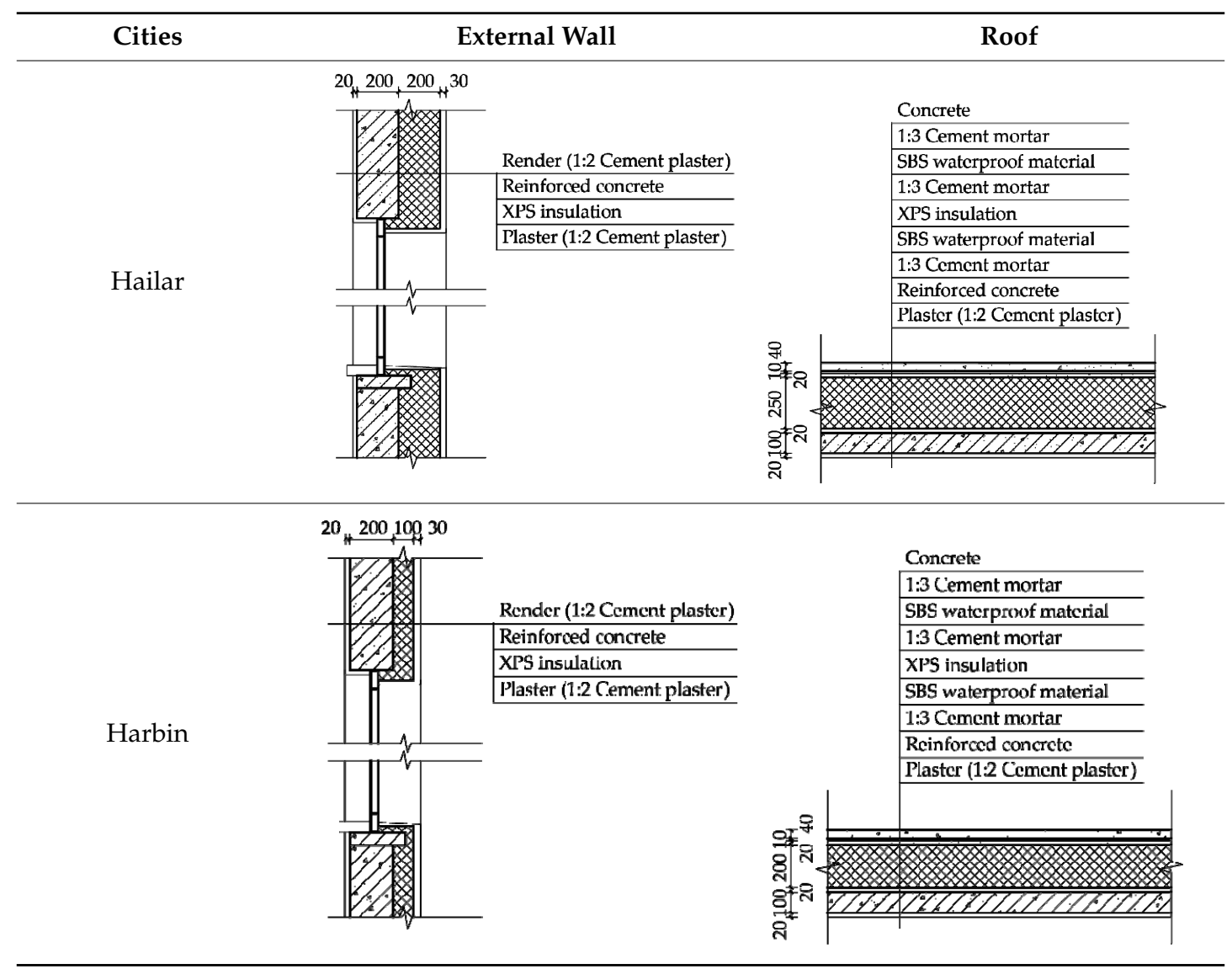


Table 5. Cont.

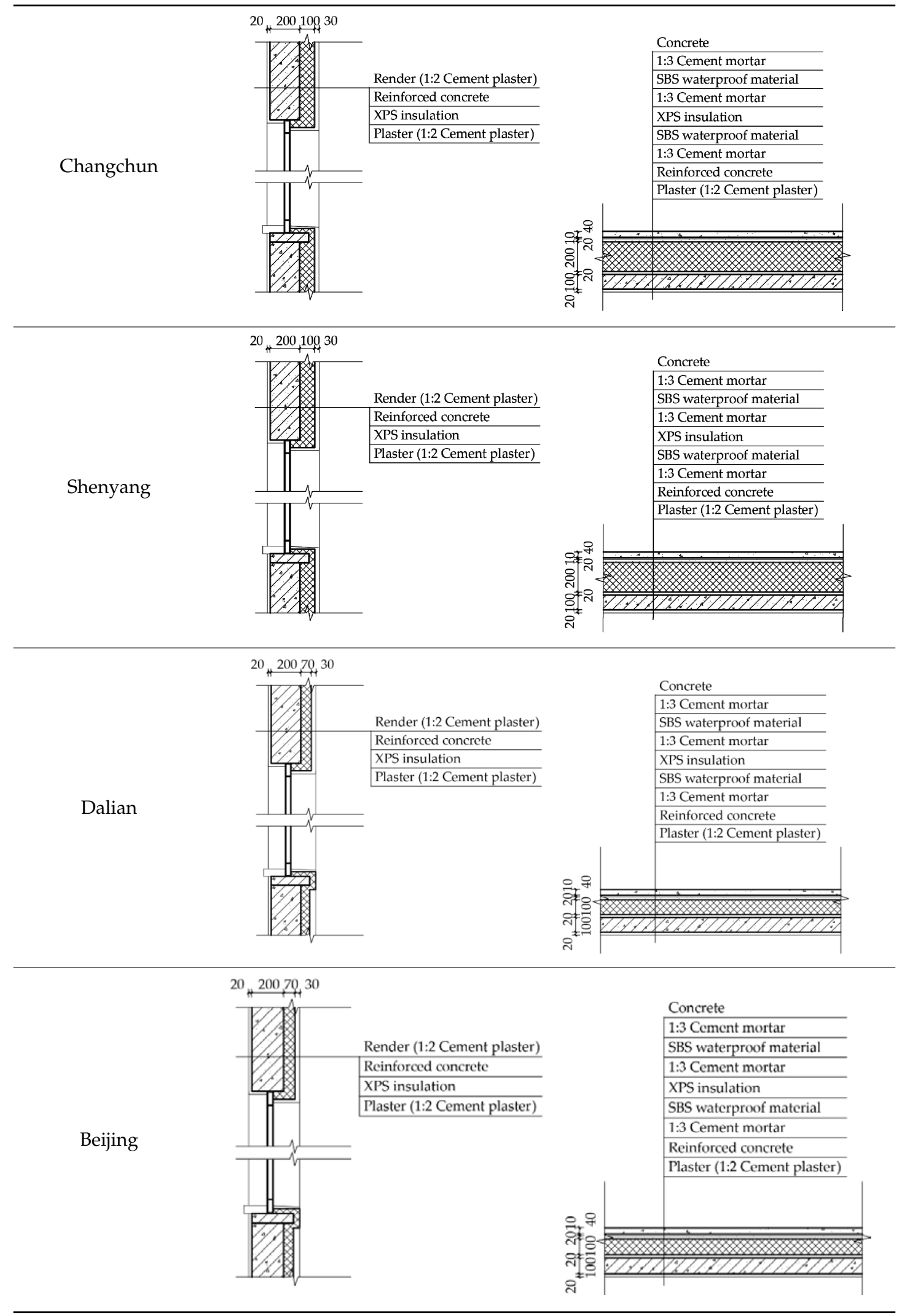

Data source: Code for thermal design of civil buildings (GB 50176-2016); drawn by the authors. 


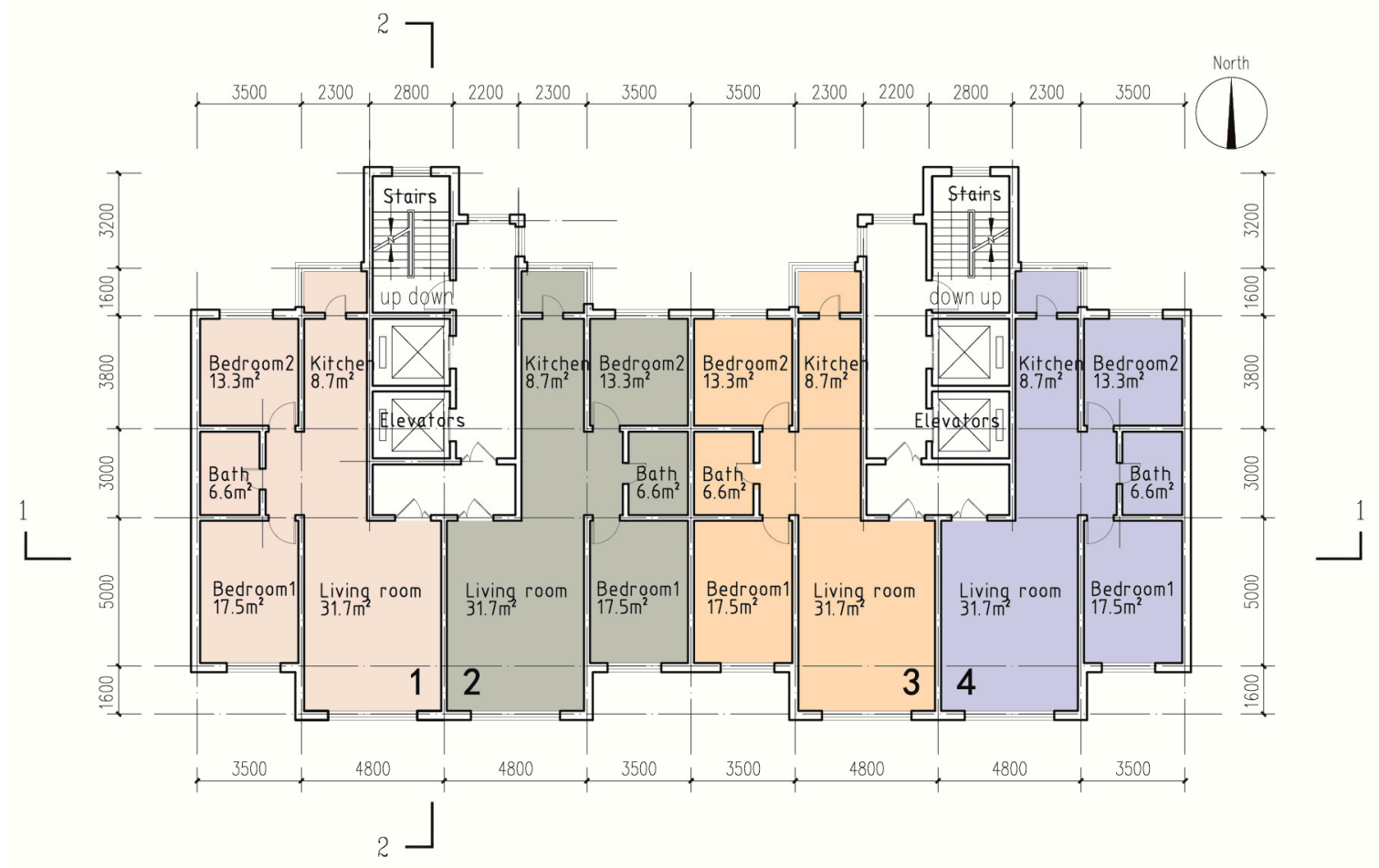

(a)

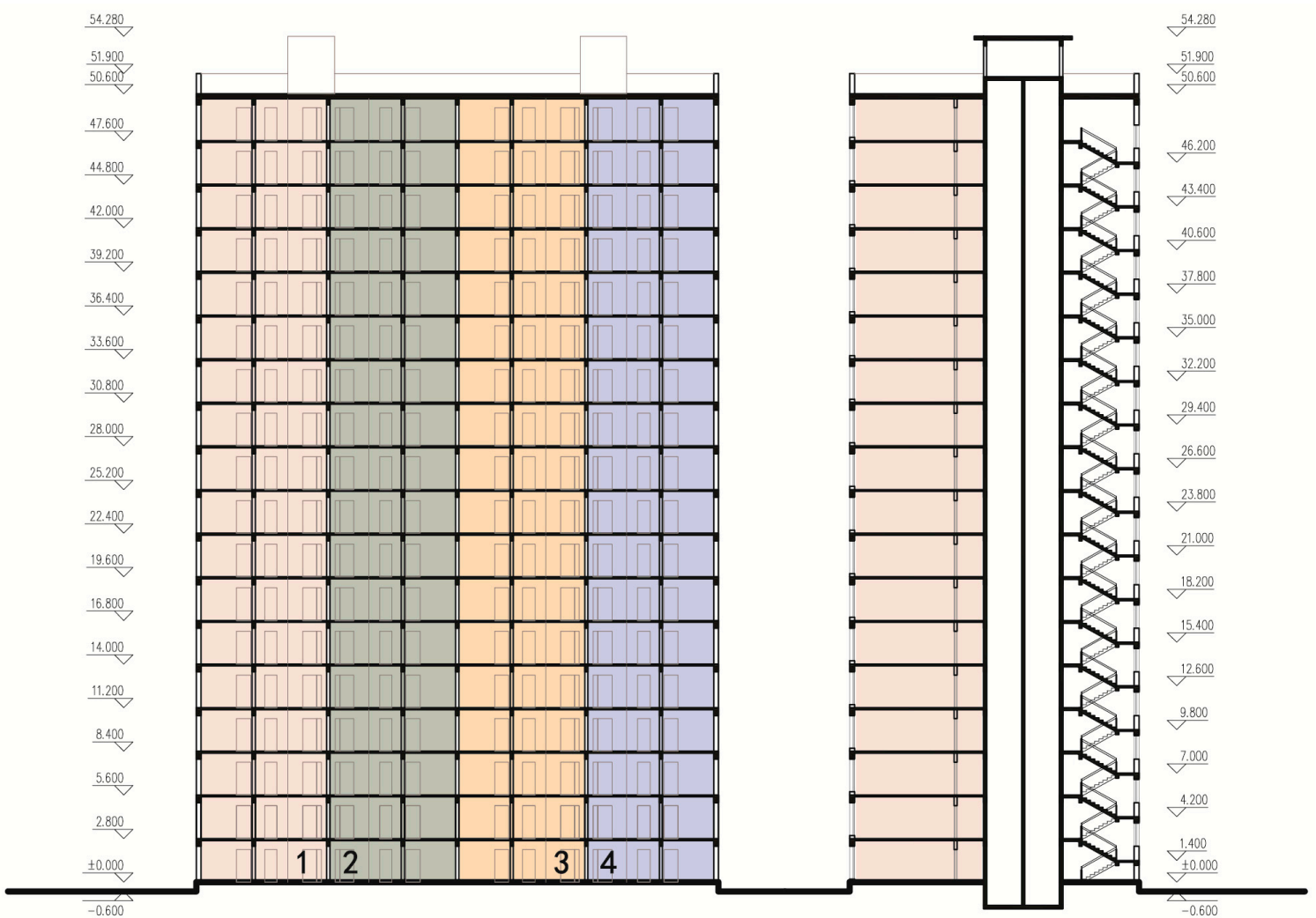

(b)

Figure 5. Details of the architectural design. (a) Standard floor plan of the residential case study building. (b) 1-1 and 2-2 sections of the building. 


\subsubsection{The CLT Building}

At present, there are no CLT residential building design standards in China, so EN 15251 (European standard) and other related documents were adopted as the design standards for the CLT structure in this study. The thickness of the thermal insulation and the CLT panels were adjusted for the different thermal zones to meet the requirements of local thermal design and envelope design codes. The basic design parameters of the two simulated buildings remained the same. The stairs of the timber buildings were assumed to be built by using concrete. The detailed design parameters for the six-case study CLT scenarios are presented in Table 6.

Table 6. External wall and roof designs for the CLT residential buildings in the six cities.

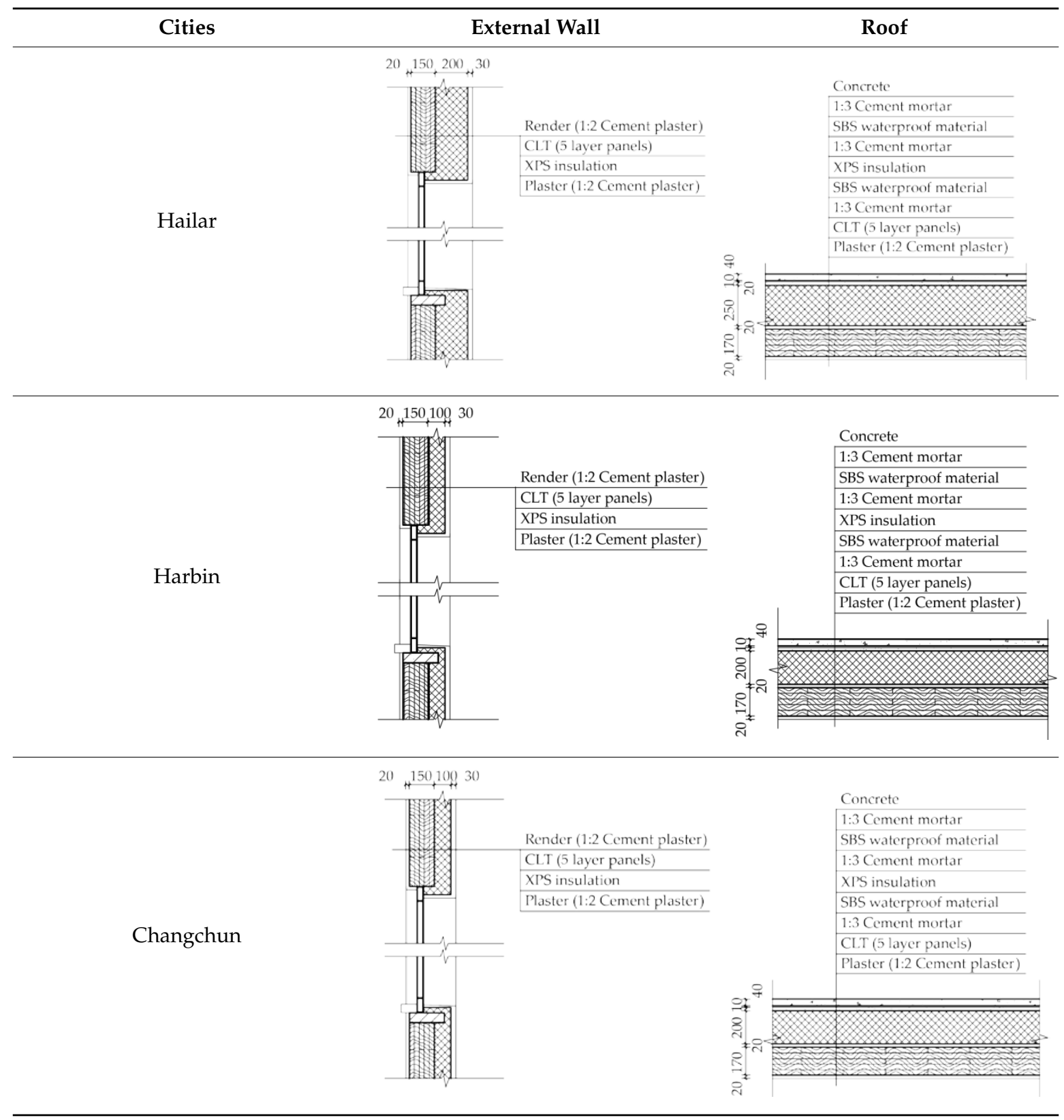


Table 6. Cont.

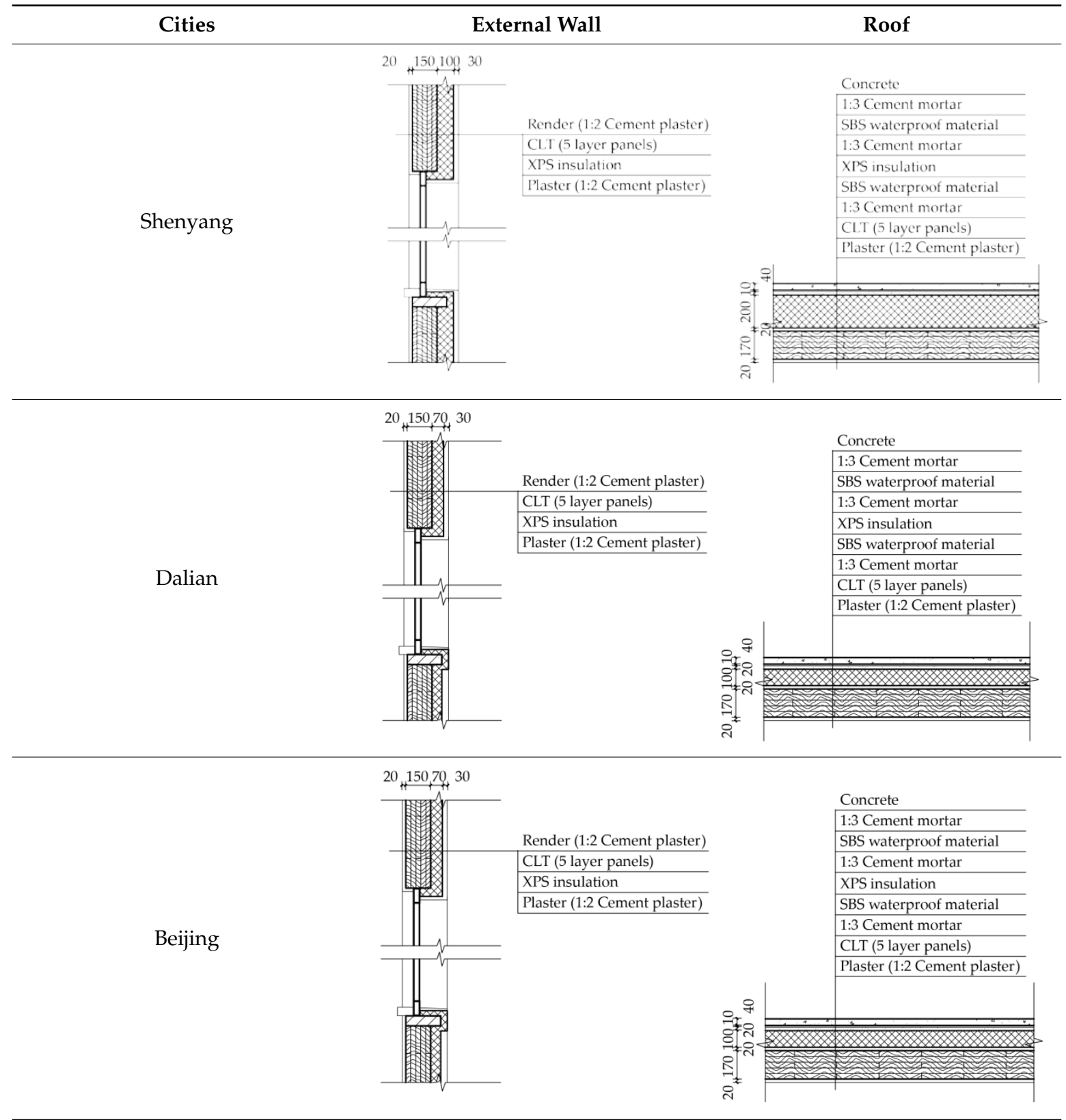

Data source: Code for thermal design of civil buildings (GB 50176-2016); drawn by the authors.

\subsection{Simulation Parameters}

This study simulates the indoor operative temperature and cooling energy consumption during the summer with the software IES-VE. In the software platform, the reinforced concrete and timber buildings are established as separate simulation models. The following assumptions are made for simplification of the simulation.

(1) Simulation rooms. In order to study the temperature differences in the various rooms in a single apartment, the temperature of bedroom 1 (facing south), bedroom 2 (facing north) and the living room (facing south) are investigated separately (Figure 6). In the simulation, the door of each room is taken to be open or closed depending on the operation of the cooling system. The basic settings are tabulated in Table 9. 
(2) Space Cooling. Apache Systems (ApSys) in the IES VE, which is a simplified HVAC methodology, is adopted for the simulation. This paper focuses on the potential overheating phenomenon in residential buildings in summer. As a result, heating parameter settings are not considered. For the cooling settings, the energy efficiency ratio (EER) of the cooling system is set to be $2.5000 \mathrm{~kW} / \mathrm{kW}$. According to the Code for thermal design of civil buildings (GB 50176-2016), comfortable temperatures in summer should not exceed $26^{\circ} \mathrm{C}$. In the simulation, the cooling system is automatically put into operation if the indoor temperature exceeds $26^{\circ} \mathrm{C}$ during occupied hours. The basic parameters for the cooling operation settings are shown in Table 7.

(3) Ventilation. In the study, both natural ventilation and infiltration are considered in the simulation. According to the rules from the design standard for heating ventilation and air conditioning of civil buildings (GB 50736-2012), the basic parameters for natural ventilation are shown in Table 8. The natural ventilation and infiltration air change rates of bedroom 1, bedroom 2, and living room are set to be $1.0 \mathrm{~h}^{-1}$ and $0.3 \mathrm{~h}^{-1}$ in this study. The ventilation times is set based on the habits of the local residents. For example, the average daily temperature of winter in Harbin, which is located in a severe cold region, is lower than $-20^{\circ} \mathrm{C}$. The local residents open the window for ventilation at a regular time in the morning or evening.

1 Bedroom 1: $17.5 \mathrm{~m}^{2}$

2 Bedroom 2: $13.3 \mathrm{~m}^{2}$

3 Living room: $31.7 \mathrm{~m}^{2}$

4 Kitchen: $8.7 \mathrm{~m}^{2}$

5 Bath: $6.6 \mathrm{~m}^{2}$
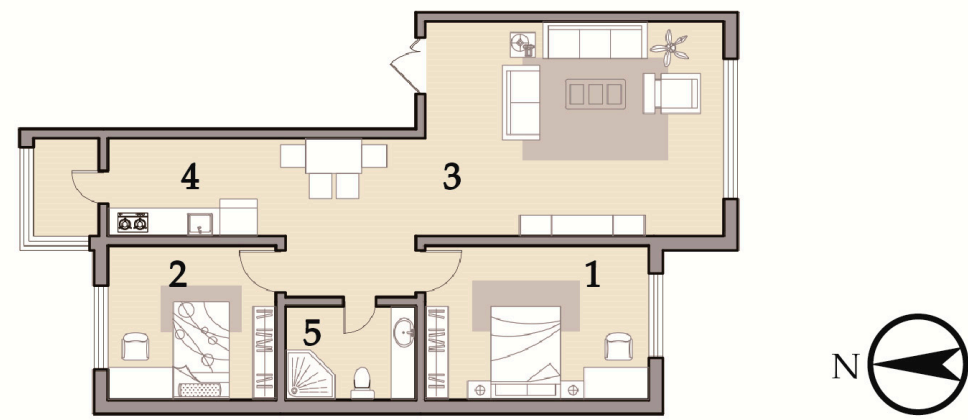

Figure 6. The layout of the apartment. (Data source: drawn by the authors).

Table 7. Simulation parameters for cooling operation in the six cities.

\begin{tabular}{|c|c|c|c|c|}
\hline Room & Cooling Set Point & Cooling Month & \multicolumn{2}{|c|}{ Working Time } \\
\hline $\begin{array}{l}\text { Bedroom } 1 \\
\text { Bedroom } 2\end{array}$ & \multirow{3}{*}{$26^{\circ} \mathrm{C}$} & \multirow{3}{*}{15 June-15 September } & \multicolumn{2}{|c|}{ 22:00-7:00 (next day) } \\
\hline \multirow{2}{*}{ Living room } & & & workday & 18:00-22:00 \\
\hline & & & weekend & 14:00-22:00 \\
\hline
\end{tabular}

Data source: Code for thermal design of civil buildings (GB 50176-2016).

Table 8. Simulation parameters for natural ventilation.

\begin{tabular}{|c|c|c|c|c|}
\hline Room & Ventilation Month & Ventilation Time & Ventilation Condition & Air Changes Rate $\left(h^{-1}\right)$ \\
\hline \multirow{3}{*}{$\begin{array}{c}\text { Bedroom } 1 \\
\text { Bedroom } 2 \\
\text { Living room }\end{array}$} & 1 May-14 June & $\begin{array}{c}7: 00-9: 00 \\
16: 00-18 \cdot 00\end{array}$ & On continuously & \multirow{3}{*}{1.0} \\
\hline & 15 June-15 September & $\begin{array}{l}7: 00-9: 00 \\
17: 00-22: 00\end{array}$ & $\begin{array}{c}\text { Outdoor Temp }<26^{\circ} \mathrm{C} \\
\text { and Room Temp }> \\
\text { Outdoor Temp }\end{array}$ & \\
\hline & 16 September-30 September & $\begin{array}{c}\text { 7:00-9:00 } \\
16: 00-18: 00\end{array}$ & On continuously & \\
\hline
\end{tabular}

Data source: Design code for heating ventilation and air conditioning of civil buildings (GB 50736-2012). 
Table 9. Open/closed time of the doors in the simulation.

\begin{tabular}{|c|c|c|c|}
\hline \multicolumn{2}{|l|}{ Type } & Conditions & Open Time \\
\hline \multicolumn{2}{|c|}{ Entrance door } & - & Closed continuously \\
\hline \multirow{4}{*}{ The doors of rooms } & \multirow[t]{2}{*}{ Bedrooms } & With air conditioning & $\begin{array}{l}\text { Closed continuously at 22:00-7:00 (next day) } \\
\text { on } 15 \text { June-15 September }\end{array}$ \\
\hline & & Without air conditioning & Open continuously \\
\hline & \multirow{2}{*}{$\begin{array}{l}\text { Other } \\
\text { rooms }\end{array}$} & With air conditioning & \multirow{2}{*}{ Open continuously } \\
\hline & & Without air conditioning & \\
\hline
\end{tabular}

\section{Results and Analysis}

(1) Cooling loads and operative temperatures.

The estimated cooling energy consumption for the RC and CLT buildings is presented in Table 10. The results indicate that in summer, the average cooling energy consumption in CLT buildings is higher than that in the RC buildings. In the severe cold region, the CLT buildings consume from $20.97 \%$ to $42.93 \%$ of additional cooling energy when compared with the RC buildings. In the cold region, the figures drop to $2.2 \%$ to $19.3 \%$. The difference in cooling energy consumption between CLT and RC buildings in Beijing is not significant; Beijing is located in cold region 2B.

Table 10. Cooling energy consumption in the six cities $\left(\mathrm{kJ} / \mathrm{m}^{2}\right)$.

\begin{tabular}{cccccccc}
\hline & Month & Hailar & Harbin & Changchun & Shenyang & Dalian & Beijing \\
\hline \multirow{3}{*}{ RC } & June & 21.24 & 22.68 & 22.32 & 30.60 & 33.84 & 788.40 \\
Residential & July & 77.08 & 82.80 & 81.72 & 866.16 & 898.56 & 5862.60 \\
Buildings & Sugust & 196.06 & 210.60 & 208.08 & 1040.40 & 1085.40 & 3810.24 \\
& Teptember & 0.00 & 0.00 & 0.00 & 0.00 & 0.00 & 66.24 \\
& Total & 294.37 & 316.08 & 312.12 & 1937.16 & 2017.80 & $10,527.48$ \\
\hline \multirow{2}{*}{ CLT } & June & 58.68 & 63.72 & 50.76 & 78.12 & 79.20 & 884.88 \\
Residential & July & 147.96 & 157.32 & 136.08 & 1120.68 & 1140.84 & 5987.88 \\
Buildings & August & 309.60 & 323.28 & 292.32 & 1252.08 & 1279.80 & 3793.32 \\
& September & 0.00 & 0.00 & 0.00 & 0.00 & 0.00 & 103.32 \\
& Total & 516.24 & 544.32 & 479.16 & 2450.88 & 2499.84 & $10,769.40$ \\
\hline & Ratio & $42.98 \%$ & $41.93 \%$ & $34.86 \%$ & $20.97 \%$ & $19.29 \%$ & $2.20 \%$ \\
\hline
\end{tabular}

Figure 7 presents the results for the operative temperature in bedroom 1 on the 11th floor (the middle floor) for both RC and CLT residential buildings in the six cities that are located in different climate regions. The results indicate that both the RC and the CLT buildings experience varying degrees of overheating in any climate subregion. The total overheating hours are closely related to the climate region. Table 11 presents an assessment of the overheating time in the case study buildings using the CIBSE TM59 criterion, namely that the operative temperature in the bedrooms should not exceed $26^{\circ} \mathrm{C}$ from 10:00 p.m. to 7:00 a.m. for more than $1 \%$ of the annual hours in predominantly naturally ventilated dwellings [17]. CIBSE TM59 recommends occupied hours as $3672 \mathrm{~h}$ per year for bedrooms ( $24 \mathrm{~h}$ for the May-September dates covered) and $1989 \mathrm{~h}$ per year for living rooms (13 $\mathrm{h}$ per day for the May-September dates covered). This provides a useful check that profiles have been correctly applied. The estimated results show that operative temperature in bedrooms exceeding $26^{\circ} \mathrm{C}$ in the summer increases gradually from north to south. None of the rooms meet the thermal comfort standards based on CIBSE 59. 

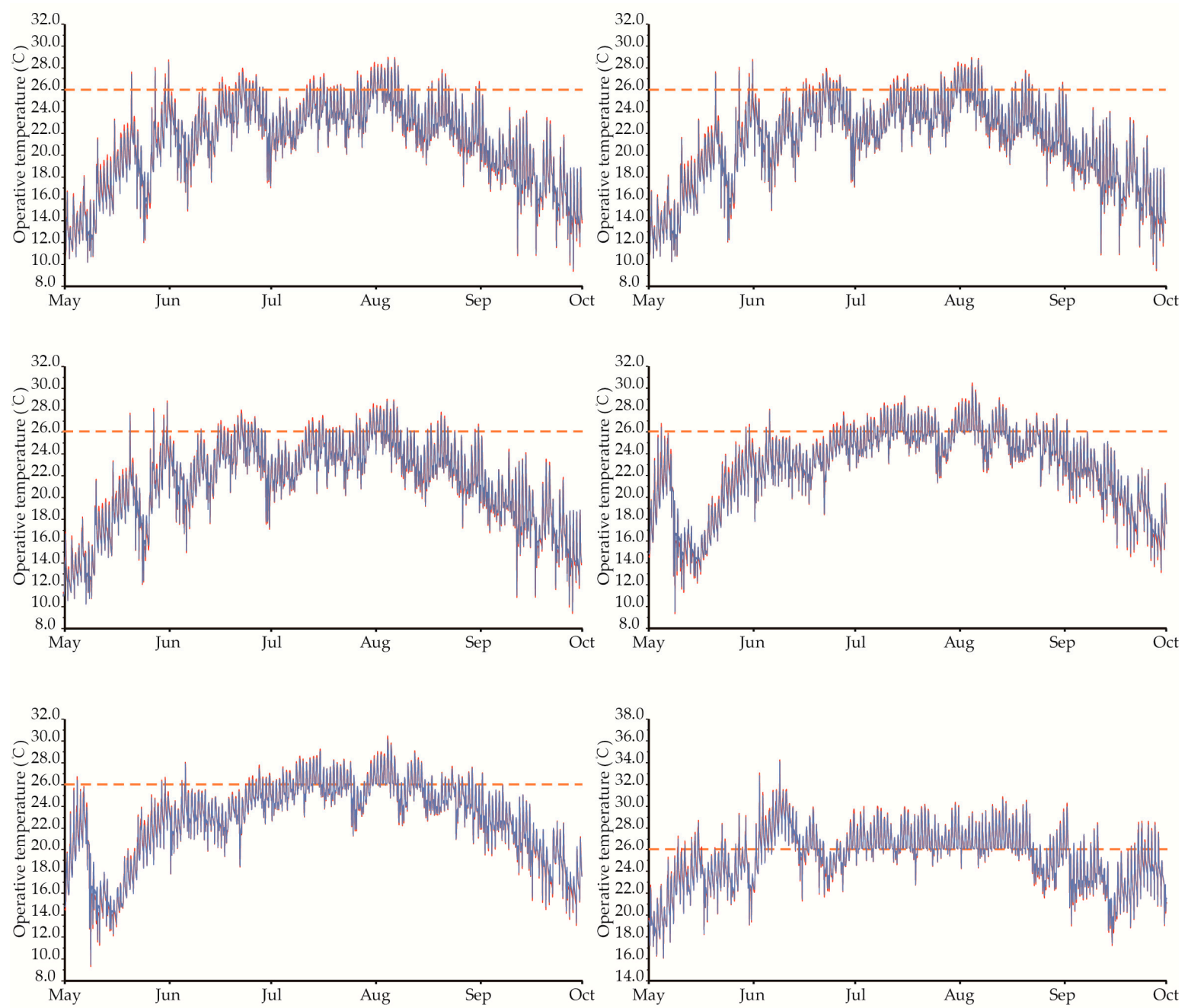

RC buildings

CLT buildings

----- Operative temperature is $26^{\circ} \mathrm{C}$

Figure 7. Operative temperature in bedroom 1 on the 11th floor in the RC and CLT building. (Data source: drawn by the authors).

The results also restate the research findings for other residential buildings that are located at the same latitude as the areas studied. The calculations results, tabulated in Table 12, showed that the degree of overheating problem in the severe cold region of China is similar to that in Austria, UK, and Canada. However, in the cold region of China, the overheating problem appears to be more serious than these other regions. In view of the thermal comfort in the summer, it is an imminent task for managers of residential buildings in the cold region of China to solve the overheating problem.

(2) Apartment level.

The results from the building simulation presented in Figure 8 indicate that the level of the apartment is a major factor having a bearing on summer energy performance and indoor temperature. The simulation results for energy consumption and the operative temperatures indicate that apartments on higher floors experience an increase in energy consumption and overheating. The energy consumption on the ground floor of the building is lower than on all other floors. The total overheating hours on the ground floor are from $80.31 \%$ to $92.27 \%$ of the average for the building. 
$\mathrm{RC}$

$18 \mathrm{~F}=\mathrm{m}$

$17 \mathrm{~F}$

$16 \mathrm{~F}$

$15 \mathrm{~F}=$

$14 \mathrm{~F}=$

$13 \mathrm{~F}=\mathrm{a}$

$12 \mathrm{~F}$

$11 \mathrm{~F}$ त्व

$10 \mathrm{~F}$

$9 \mathrm{~F}$ त्व

$8 \mathrm{~F}$

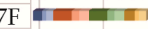

$6 \mathrm{~F} \pi \mathrm{r}=\mathrm{m}$

$5 \mathrm{~F}=$

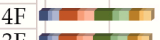

2F

$2 \mathrm{~F}$

$\begin{array}{lllllllllll}0 & 1000 & 2000 & 3000 & 4000 & 5000 & 4000 & 3000 & 2000 & 1000 & 0\end{array}$ The number of hours (h)

RC

$18 \mathrm{~F}$

$17 \mathrm{~F}$

$16 \mathrm{~F}$

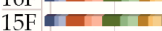

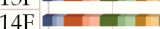

$14 \mathrm{~F}$

$3 \mathrm{~F}=\mathrm{m}$

$2 \mathrm{~F}$ -

$11 \mathrm{~F}$

$10 \mathrm{~F}$

$8 \mathrm{~F}$

$7 \mathrm{~F}$

$6 \mathrm{~F}$

$5 \mathrm{~F}$

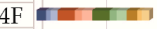

$3 \mathrm{~F}$

$2 \mathrm{~F}$

$1 \mathrm{~F}$

$0 \quad 1000 \quad 2000 \quad 3000$

The number of hours (h)
$\mathrm{RC}$

$18 \mathrm{~F}$ 때

$17 \mathrm{~F}$ त्व

$16 \mathrm{~F}$ -

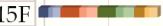

$14 \mathrm{~F}$ त्व

$13 \mathrm{~F}$

$12 \mathrm{~F}$ का

$11 \mathrm{~F}$

$11 \mathrm{~F}$ 마맘

$10 \mathrm{~F}$

$9 \mathrm{~F}$ -

$8 \mathrm{~F}$ त्

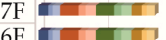

$6 \mathrm{~F}$

$4 \mathrm{~F}$

$3 \mathrm{~F}$

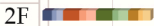

$\frac{2 \mathrm{~F}}{1 \mathrm{~F}}$ $\frac{2 \mathrm{~F}}{1 \mathrm{~F}}$

CLT

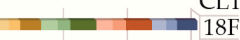

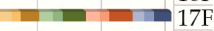
맘 $16 \mathrm{~F}$ $15 \mathrm{~F}$ $14 \mathrm{~F}$ $13 \mathrm{~F}$ $12 \mathrm{~F}$ $11 \mathrm{~F}$ $10 \mathrm{~F}$ प $9 \mathrm{~F}$ $8 \mathrm{~F}$ 7F $6 \mathrm{~F}$ $5 \mathrm{~F}$ $4 \mathrm{~F}$ ( $3 \mathrm{~F}$ The number of hours $(h)$
$\mathrm{RC}$
$18 \mathrm{~F}+\mathrm{F}-\mathrm{m}$
$17 \mathrm{~F}$
$16 \mathrm{~F}$ - 마

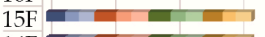
$14 \mathrm{~F}=\sqrt{13+m}$
$13 \mathrm{~F}=$
$12 \mathrm{~F}$
$12 \mathrm{~F}=-\square$
$11 \mathrm{~F}=$
$\frac{10 \mathrm{~F}}{9 \mathrm{~F}+\mathrm{E}}$
$8 \mathrm{~F}$ 맘

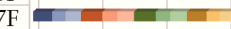
$6 \mathrm{~F}+\mathrm{rar}$
$5 \mathrm{~F}=1+\square$
$4 \mathrm{~F}$
$3 \mathrm{~F}$
$2 \mathrm{~F}$
$1 \mathrm{~F}$
CLT
$+18 \mathrm{~F}$ $\longrightarrow \frac{18 \mathrm{~F}}{\square-17 \mathrm{~F}}$ $16 \mathrm{~F}$ $15 \mathrm{~F}$ 마 $14 \mathrm{~F}$ ए $13 \mathrm{~F}$ $12 \mathrm{~F}$ $\square-11 \mathrm{~F}$ $10 \mathrm{~F}$ $\square \frac{10 \mathrm{~F}}{9-2}$ $9 \mathrm{~F}$
$8 \mathrm{~F}$ $7 \mathrm{~F}$

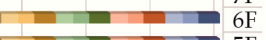 $5 \mathrm{~F}$ $4 \mathrm{~F}$ $3 \mathrm{~F}$
$2 \mathrm{~F}$
$\square \square$ $\begin{array}{lllllllllll}0 & 2000 & 4000 & 6000 & 8000 & 10,000 & 8000 & 6000 & 4000 & 2000 & 0\end{array}$
The number of hours (h)

$\mathrm{RC}$

$18 \mathrm{~F}$

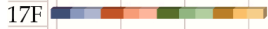

$16 \mathrm{~F}=-10$

$15 \mathrm{~F}$

$14 \mathrm{~F}$

$13 \mathrm{~F}$

$12 \mathrm{~F}$

$11 \mathrm{~F}$

$10 \mathrm{~F}$

$9 \mathrm{~F}$

$8 \mathrm{~F}$

$7 \mathrm{~F}$

$6 \mathrm{~F}$

$5 \mathrm{~F}$

$4 \mathrm{~F}$

$2 \mathrm{~F}$ व

$1 \mathrm{~F}$

$600040002000 \quad 0$

The number of hours (h)

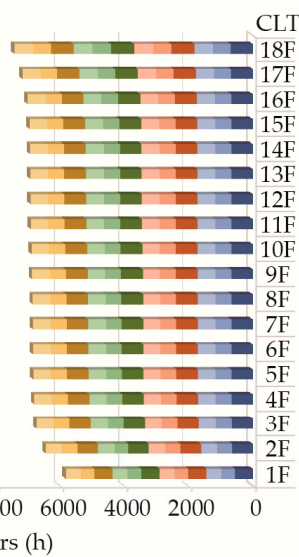

$\mathrm{RC}$

$18 \mathrm{~F}$

$17 \mathrm{~F}$

$16 \mathrm{~F}$

$15 \mathrm{~F}$

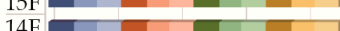

$13 \mathrm{~F}$

$12 \mathrm{~F}$ -

$12 \mathrm{~F}$

$11 \mathrm{~F}$ 마

$10 \mathrm{~F}$

9F

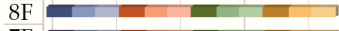

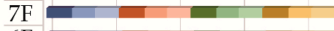

$6 \mathrm{~F}$

n

(19)

- m r mar

$\begin{array}{lllllllllll}0 & 4400 & 8800 & 13,200 & 17,600 & 22,000 & 17,600 & 13,200 & 8800 & 4400 & 0\end{array}$

The number of hours (h)
1-Bedroom1
1-Bedroom2
1-Living room
2-Bedroom1
2-Bedroom2
2-Living room
3-Bedroom1
3-Bedroom2
3-Living room
4-Bedroom1
4-Bedroom2
4-Living room

Figure 8. The number of hours where the operative temperature exceeds $26^{\circ} \mathrm{C}$ from May to September. 
Table 11. Assessment of overheating in RC and CLT buildings (11th floor) based on CIBSE TM 59.

\begin{tabular}{|c|c|c|c|c|c|c|c|}
\hline \multirow{2}{*}{ Buildings } & \multirow{2}{*}{ Cities } & \multicolumn{3}{|c|}{ Operative Temperature over $26^{\circ} \mathrm{C}(\mathrm{h})$} & \multicolumn{3}{|c|}{ CIBSE TM 59(\%) } \\
\hline & & Bedroom 1 & Bedroom 2 & Living Room & Bedroom 1 & Bedroom 2 & Living Room \\
\hline \multirow{6}{*}{ RC Residential Buildings } & Hailar & 292 & 112 & 159 & $7.95 \%$ & $3.05 \%$ & $7.99 \%$ \\
\hline & Harbin & 287 & 115 & 159 & $7.82 \%$ & $3.13 \%$ & $7.99 \%$ \\
\hline & Changchun & 281 & 114 & 158 & $7.65 \%$ & $3.10 \%$ & $7.94 \%$ \\
\hline & Shenyang & 677 & 475 & 529 & $18.44 \%$ & $12.94 \%$ & $26.60 \%$ \\
\hline & Dalian & 675 & 471 & 530 & $18.38 \%$ & $12.83 \%$ & $26.65 \%$ \\
\hline & Beijing & 1771 & 1527 & 1653 & $48.23 \%$ & $41.58 \%$ & $83.11 \%$ \\
\hline \multirow{6}{*}{ CLT Residential Buildings } & Hailar & 349 & 146 & 198 & $9.50 \%$ & $3.98 \%$ & $9.95 \%$ \\
\hline & Harbin & 339 & 147 & 198 & $9.23 \%$ & $4.00 \%$ & $9.95 \%$ \\
\hline & Changchun & 333 & 145 & 194 & $9.07 \%$ & $3.95 \%$ & $9.75 \%$ \\
\hline & Shenyang & 686 & 499 & 552 & $18.68 \%$ & $13.59 \%$ & $27.75 \%$ \\
\hline & Dalian & 684 & 501 & 555 & $18.63 \%$ & $13.64 \%$ & $27.90 \%$ \\
\hline & Beijing & 1756 & 1515 & 1647 & $47.82 \%$ & $41.26 \%$ & $82.81 \%$ \\
\hline
\end{tabular}


Table 12. Comparison of building overheating hours at the same latitude in the northern hemisphere.

\begin{tabular}{|c|c|c|c|c|}
\hline \multirow{2}{*}{ Countries/Regions } & \multicolumn{2}{|c|}{ Overheating Hours (h) } & \multirow{2}{*}{ Studied Conditions } & \multirow{2}{*}{ Ref. } \\
\hline & Bedrooms & $\begin{array}{l}\text { Living } \\
\text { Rooms }\end{array}$ & & \\
\hline UK & 2 & 187 & Mechanically ventilated house at $60 \%$ glazing ratio at top position with south facing. & [36] \\
\hline UK & 197 & 48 & $\begin{array}{l}\text { Prefabricated timber house which the bedroom is } 9.1 \mathrm{~m}^{2} \text { in second floor facing southeast and } \\
\text { the living room is } 18.3 \mathrm{~m}^{2} \text { in the ground floor facing southwest in end-terraced. }\end{array}$ & {$[30]$} \\
\hline Austria (Europe) & 252 & 42 & $\begin{array}{l}\text { Base case of single family houses with the energy renovation in Austria which } 9.5 \% \text { of the } \\
\text { occupied hours (2800) over } 26^{\circ} \mathrm{C} \text { for bedroom facing southwest and } 1.5 \% \text { of the occupied hours } \\
\text { over } 28{ }^{\circ} \mathrm{C} \text { for living rooms from } 1 \text { May to } 30 \text { September. }\end{array}$ & [44] \\
\hline Canada & 274 & - & $\begin{array}{l}\text { Single-family detached house that meets current National Energy Code of Canada for Buildings } \\
\text { (NECB) with natural ventilation and } 5 \% \text { of the summer with temperature over } 26^{\circ} \mathrm{C} \text {. }\end{array}$ & [45] \\
\hline Canada & 454 & - & $\begin{array}{l}\text { Retrofitted house meeting the Passive Haus (PH) standard in current year (2013) and 5.19\% of a } \\
\text { year with temperature over } 26^{\circ} \mathrm{C} \text {. }\end{array}$ & [46] \\
\hline Severe cold region of China & 287 & 159 & The 18-story RC building in Harbin. & - \\
\hline Cold region of China & 675 & 530 & The 18-story RC building in Dalian. & - \\
\hline
\end{tabular}

Data source: summarized by the authors from the references. 


\section{Discussion}

(1) Suggestions for the revision of building design code.

Figure 9 shows that in the severe cold region, there are two or three overheating periods which are not continuous in Hailar, Harbin, Changchun, and Shenyang. The duration of overheating in the RC case study buildings is 51,59,54, and 67 days per year, respectively. In the CLT case study building, this period is from 10 to 20 days longer. In the cold regions, the overheating period is longer and continuous, lasting from 69 to 110 days per year for the RC case study building. It should be noted that overheating days in Beijing account for over $71.8 \%$ of the summer period (from May to September), which indicates a serious indoor overheating problem due to the high thermal insulation.

The national design standard for energy efficiency of residential buildings in severe cold and cold zones of China (JGJ 26-2018) [23], issued by Ministry of Housing and Urban-Rural Development of the People's Republic of China (MOHURD), only recommends solar shading and additional natural ventilation for the cold 2B region in summer (clause 4.1). There are no definite design criteria to avoid overheating in the summer for any other subregion in the severe cold and cold region. However, the simulation results demonstrate that total hours above $26^{\circ} \mathrm{C}$ are far in excess of the criterion for overheating in dwellings. It is suggested that policy makers should promote potential designs such as movable insulation layer, shading devices, and phase change materials for the summer period in the severe cold region $(1 \mathrm{~A}, 1 \mathrm{~B}, 1 \mathrm{C})$ and the cold region $(2 \mathrm{~A}, 2 \mathrm{~B})$.

(2) Suitable Scope for CLT application.

The results indicate that CLT buildings may have more problems with overheating than RC structures; overheating in the RC case study building is of shorter duration in most of the studied cities. Biobased building materials such as timber, hemp, and straw bales may have overheating problems in summer due to their lower thermal mass. Keeping the indoor temperature above $18{ }^{\circ} \mathrm{C}$ for the residential buildings in the winter is the priority design task in the severe cold region and cold region. Thus, although more cooling energy is consumed in the summer, CLT buildings should be developed in such areas of China due to their excellent performance in saving heating energy. In view of saving cooling energy only, CLT may not be such a suitable building material in regions without considerable heating requirements.

(3) Potential ways to mitigate overheating.

High thermal insulation of walls is a key factor that leads to summer overheating in the severe cold and cold regions of China. Since the principal aim is to maintain indoor temperatures above $18^{\circ} \mathrm{C}$ in the winter in these regions, the high thermal insulation is deemed essential. Still, there are other ways to mitigate the overheating problem. Using light thermal insulation with the cavity wall technique is suggested to prevent summer overheating [47]. Exterior solar shading and additional natural ventilation are also effective in reducing cooling demand in the summer [48]. Makantasi et al. [49] studied the influence on thermal insulation and shading on overheating time and heating demand in a residential building, which was a 17-story tower block in Islington, London, in current and future climates. Meanwhile, they set different emission scenarios. In the high emissions scenario under 90th probability in 2050s, they found external vertical louvers reduced overheating hours by $28.4 \%$ compared to no shading; however, the demand for heating increased by $19.5 \%$ in the same situation. The movable external shading compared with the fixed reduced overheating time by $43.7 \%$ and increased the heating time by $8.3 \%$, which was a better balance, and hence it can be recommended for residential buildings located in China's severe cold and cold regions. 

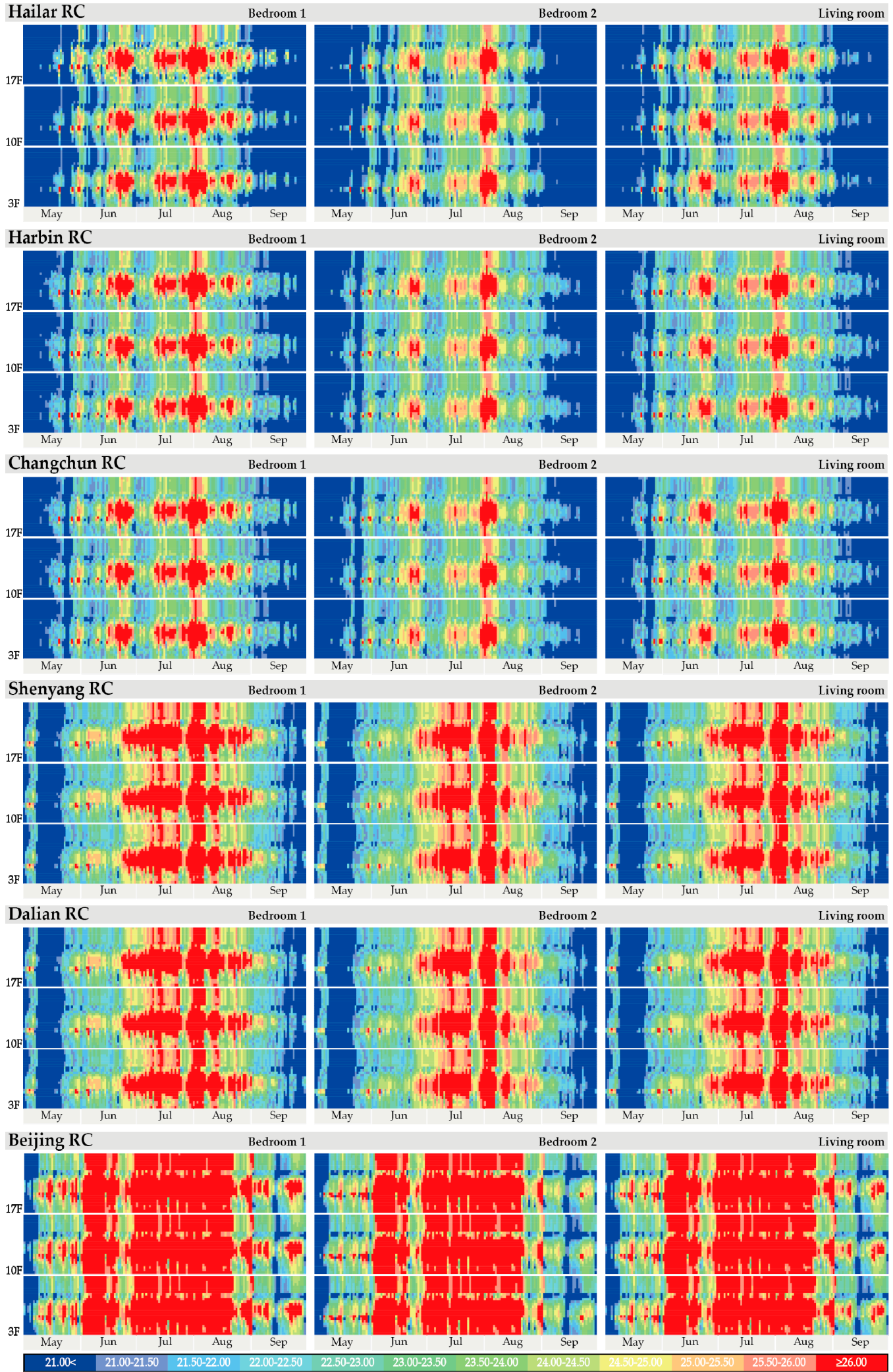

Figure 9. Operative temperature $\left({ }^{\circ} \mathrm{C}\right)$ of $3 \mathrm{~F}, 10 \mathrm{~F}$, and $17 \mathrm{~F}$ in $\mathrm{RC}$ buildings of six cities.

\section{Conclusions}

This paper describes a simulation of the cooling energy consumption and indoor temperatures in concrete and timber residential buildings to identify the potential overheating phenomenon in the 
severe cold and cold regions of China. The research reveals that the residential buildings in such areas suffer overheating problems due to climate change. The local design standard for energy efficiency needs to be promoted by adding design methods to reduce the periods of overheating in the summer. The CLT buildings have longer overheating hours compared to the RC buildings, especially in the cold regions. The main findings are summarized below.

(1) Both RC and CLT buildings experience varying degrees of overheating in these climate subregions. The extent of overheating hours depends on the climate region. Operative temperatures above $26{ }^{\circ} \mathrm{C}$ in bedrooms increase gradually from north to south. For the RC case study building, bedroom temperatures above $26^{\circ} \mathrm{C}$ in summer in Hailar, Harbin, Shenyang, Changchun, Dalian, and Beijing occur for $7.95 \%, 7.82 \%, 7.65 \%, 18.44 \%, 18.38 \%$, and $48.23 \%$ of the total occupied time, respectively. The corresponding figures for the CLT case study building in these cities are $9.50 \%$, $9.23 \%, 9.07 \%, 18.68 \%, 18.63 \%$, and $47.82 \%$, respectively.

(2) Apartments on higher floors experience an increase in energy consumption and overheating. The energy consumption on the bottom floor of the building is lower than on the other floors.

(3) In most of the cities studied, overheating hours in the RC building are less than in the timber buildings. In view of saving cooling energy only, CLT may not be such a suitable building material in regions without considerable heating requirements.

Author Contributions: Conceptualization, H.G. and L.H.; methodology, H.G.; software, L.H.; formal analysis, W.S. and X.W.; investigation, H.W. and X.Z.; resources, H.G.; data curation, X.W.; writing-original draft preparation, H.G. and L.H.; writing-review and editing, H.G. and L.H.; visualization, H.W. and X.Z.; supervision, H.G.; project administration, H.G.; funding acquisition, H.G. All authors have read and agreed to the published version of the manuscript.

Funding: This research is funded by National Natural Science Foundation of China, grant number 52078153; and Heilongiiang Provincial Natural Science Foundation of China, grant number LH2019E110.

Conflicts of Interest: The authors declare no conflict of interest.

\section{References}

1. State of the Climate: Global Climate Report for 2019; NOAA National Centers for Environmental Information: Silver Spring, MD, USA, 2019; p. 3. Available online: https://www.ncdc.noaa.gov/sotc/global/201913/ supplemental/page-3 (accessed on 1 March 2020).

2. Special Report on the Impacts of Global Warming of $1.5 \mathrm{C}$ above Pre-Industrial Levels and Related Global Greenhouse Gas Emission Pathways, in the Context of Strengthening the Global Response to the Threat of Climate Change, Sustainable Development, and Efforts to Eradicate Poverty; IPCC: Geneva, Switzerland, 2018; Available online: https://www.ipcc.ch/sr15/ (accessed on 28 November 2020).

3. Gasparri, E.; Aitchison, M. Unitised timber envelopes. A novel approach to the design of prefabricated mass timber envelopes for multi-storey buildings. J. Build. Eng. 2019, 26, 100898. [CrossRef]

4. Lomas, K.J.; Porritt, S.M. Overheating in buildings: Lessons from research. Build. Res. Inf. 2016, 45, 1-18. [CrossRef]

5. Lane, K.; Wheeler, K.; Charles-Guzman, K.; Ahmed, M.; Blum, M.; Gregory, K.; Graber, N.; Clark, N.; Matte, T. Extreme Heat Awareness and Protective Behaviors in New York City. J. Hered. 2014, 91, 403-414. [CrossRef] [PubMed]

6. Lee, W.V.; Shaman, J. Heat-coping strategies and bedroom thermal satisfaction in New York City. Sci. Total. Environ. 2017, 574, 1217-1231. [CrossRef] [PubMed]

7. Pathan, A.; Mavrogianni, A.; Summerfield, A.; Oreszczyn, T.; Davies, M. Monitoring summer indoor overheating in the London housing stock. Energy Build. 2017, 141, 361-378. [CrossRef]

8. Willand, N.; Ridley, I.; Pears, A. Relationship of thermal performance rating, summer indoor temperatures and cooling energy use in 107 homes in Melbourne, Australia. Energy Build. 2016, 113, 159-168. [CrossRef]

9. Dodoo, A.; Gustavsson, L. Energy use and overheating risk of Swedish multi-storey residential buildings under different climate scenarios. Energy 2016, 97, 534-548. [CrossRef] 
10. Yanase, T. A condition for good sleep-managements for sleep. Sleeplessness 1981, 275-285. Available online: https://ci.nii.ac.jp/naid/10024207856/en/ (accessed on 28 November 2020).

11. Davies, M.; Mavrogianni, A. Investigation into Overheating in Homes: Literature Review; Department for Communities and Local Government London: London, UK, 2012. Available online: https://www. gov.uk/government/publications/investigation-into-overheating-in-homes-literature-review (accessed on 28 November 2020).

12. Okamoto-Mizuno, K.; Tsuzuki, K.; Mizuno, K.; Iwaki, T. Effects of partial humid heat exposure during different segments of sleep on human sleep stages and body temperature. Physiol. Behav. 2005, 83, 759-765. [CrossRef]

13. Heatwave Plan for England_Protecting Health and Reducing Harm from Severe Heat and Heatwaves; Public Health England: London, UK, 2015. Available online: https://www.gov.uk/government/publications/heatwaveplan-for-england (accessed on 28 November 2020).

14. Overheating in Homes; Zero Carbon Hub: Milton Keynes, UK, 2015.

15. Hacker, J.; Holmes, M.; Belcher, S.; Davies, G. Climate Change and the Indoor Environment: Impacts and Adaptation CIBSE TM36:2005; Chartered Institution of Building Services Engineers (CIBSE): London, UK, 2005; Available online: https://www.cibse.org/knowledge/knowledge-items/detail?id=a0q20000008I71DAAS (accessed on 1 August 2018).

16. Nicol, F. The Limits of Thermal Comfort: Avoiding Overheating in European Buildings: CIBSE TM52, 2013; Cibse: London, UK, 2013; Available online: https://www.cibse.org/Knowledge/knowledge-items/detail?id= a0q20000008I7f5AAC (accessed on 28 November 2020).

17. Bonfigli, C.; Chorafa, M.; Diamond, S.; Eliades, C.; Mylona, A.; Taylor, B.; Virk, D. Design Methodology for the Assessment of Overheating Risk in Homes CIBSE TM59:2017; The Chartered Institution of Building Services Engineers (CIBSE): London, UK, 2017; Available online: https://www.cibse.org/knowledge/knowledge-items/ detail?id=a0q0O00000DVrTdQAL (accessed on 28 November 2020).

18. ANSI/ASHRAE Standard 55-2017 Thermal Environmental Conditions for Human Occupancy; American Society of Heating, Refrigerating Air Conditioning Engineers (ASHRAE): Atlanta, GA, USA, 2017; Available online: https://www.ashrae.org/technical-resources/bookstore/standard-55-thermal-environmental-conditionsfor-human-occupancy (accessed on 28 November 2020).

19. Indoor Environmental Input Parameters for Design Assessment of Energy Performance of Buildings Addressing Indoor Air Quality, Thermal Environment, Lighting Acoustics BS EN 15251: 2007; Comite Europeen de Normalisation: Brussels, Belgium, 2007.

20. Next Steps in Defining Overheating: A Discussion Paper; Zero Carbon Hub: Milton Keynes, UK, 2016.

21. Feist, W.; Pfluger, R.; Kaufmann, B.; Schnieders, J.; Kah, O. Passive House Planning Package 2007 Specifications for Quality Approved Passive Houses; Passive House Institute: Darmstadt, German, 2007.

22. Code for Thermal Design of Civil Building GB 50176-2016; Mohurd (Ed.) China Architecture \& Building Press: Beijing, China, 2016. Available online: http://www.mohurd.gov.cn/wjfb/201702/t20170213_230579.html (accessed on 28 November 2020).

23. Design Standard for Energy Efficiency of Residential Buildings in Severe Cold and Cold Zones JGJ 26-2018; Mohurd, Ed.; China Architecture \& Building Press: Beijing, China, 2018. Available online: http://www. mohurd.gov.cn/wjfb/201909/t20190910_241751.html (accessed on 28 November 2020).

24. Fourteenth of the Series of Reports on the Economic and Social Development Achievements of the 70th Anniversary of the Founding of New China; National Bureau of Statistics: Beijing, China, 2019. Available online: http://www. stats.gov.cn/ztjc/zthd/bwcxljsm/70znxc/201908/t20190809_1690097.html (accessed on 28 November 2020).

25. Green Building Action Plan; National Development and Reform Comission, Ministry of Housing and Urban-Rural Development of the People's Republic of China: Beijing, China, 2015. Available online: http://www.nea.gov.cn/2013-01/07/c_132085767.htm (accessed on 28 November 2020).

26. Mao, D.; He, X.; Wang, Z.; Tian, Y.; Xiang, H.; Yu, H.; Man, W.; Jia, M.; R, C.; Zheng, H. Diverse policies leading to contrasting impacts on land cover and ecosystem services in Northeast China. J. Clean. Prod. 2019, 240, 117961. [CrossRef]

27. Brandner, R.; Flatscher, G.; Ringhofer, A.; Schickhofer, G.; Thiel, A. Cross laminated timber (CLT): Overview and development. Eur. J. Wood Wood Prod. 2016, 74, 331-351. [CrossRef]

28. Dodoo, A.; Gustavsson, L.; Sathre, R. Lifecycle carbon implications of conventional and low-energy multi-storey timber building systems. Energy Build. 2014, 82, 194-210. [CrossRef] 
29. Setter, L.; Smoorenburg, E.; Wijesuriya, S.; Tabares-Velasco, P.C. Energy and hygrothermal performance of cross laminated timber single-family homes subjected to constant and variable electric rates. J. Build. Eng. 2019, 25, 100784. [CrossRef]

30. Adekunle, T.O.; Nikolopoulou, M. Thermal comfort, summertime temperatures and overheating in prefabricated timber housing. Build. Environ. 2016, 103, 21-35. [CrossRef]

31. Mavrogianni, A.; Pathan, A.; Oikonomou, E.; Biddulph, P.; Symonds, P.; Davies, M. Inhabitant actions and summer overheating risk in London dwellings. Build. Res. Inf. 2016, 45, 119-142. [CrossRef]

32. Sharifi, S.; Saman, W.; Alemu, A. Identification of overheating in the top floors of energy-efficient multilevel dwellings. Energy Build. 2019, 204, 109452. [CrossRef]

33. Pajek, L.; Hudobivnik, B.; Kunič, R.; Košir, M. Improving thermal response of lightweight timber building envelopes during cooling season in three European locations. J. Clean. Prod. 2017, 156, 939-952. [CrossRef]

34. Hudobivnik, B.; Pajek, L.; Kunič, R.; Košir, M. FEM thermal performance analysis of multi-layer external walls during typical summer conditions considering high intensity passive cooling. Appl. Energy 2016, 178, 363-375. [CrossRef]

35. Kuczyński, T.; Staszczuk, A. Experimental study of the influence of thermal mass on thermal comfort and cooling energy demand in residential buildings. Energy 2020, 195, 116984. [CrossRef]

36. Nebia, B.; Aoul, K.A.T. Overheating and Daylighting; Assessment Tool in Early Design of London's High-Rise Residential Buildings. Sustainability 2017, 9, 1544. [CrossRef]

37. Su, Y.; Pu, M.; Liu, C. Analysis on thermal comfort in summer of typical old residential area in Dalian. Urban. Archit. 2018, 27-30. (In Chinese)

38. Yan, H.; Hao, L.; Yang, 1.; Zheng, W.; Li, D. Indoor Environment and Thermal Comfort of Residential Buildings in Yinchuan in Summer. Build. Sci. 2015, 31, 20-27. (In Chinese)

39. Yang, L.; Zhou, S.; Yan, H.; Zou, M.; Gao, L. Field research of indoor thermal comfort in summer for residential buildings in Baotou. J. Xi'an Univ. Archit. Technol. 2012, 44, 369-375. (In Chinese)

40. Mao, Y.; Liu, J.; Yang, l. Investigation and analysis on indoor thermal environment in summer for residential building in cold zone. J. HARBIN Inst. Technol. 2009, 41, 238-240. (In Chinese)

41. Wang, Z.; Zhang, L.; Zhao, J.; He, Y. Thermal comfort for naturally ventilated residential buildings in Harbin. Energy Build. 2010, 42, 2406-2415. [CrossRef]

42. Yan, H.; Yang, L. Field study on occupant thermal comfort in residential buildings of Jiaozuo city in summer. Heat. Vent. Air. Cond. 2012, 42, 96-103. (In Chinese)

43. Song, Y. Study on Thermal Comfort and Occupants' Adaptive Behaviors in Tianjin Residential Buildings. Master's Thesis, Tianjin University, Tianjing, China, 2018. (In Chinese).

44. Psomas, T.; Heiselberg, P.; Duer, K.; Bjørn, E. Overheating risk barriers to energy renovations of single family houses: Multicriteria analysis and assessment. Energy Build. 2016, 117, 138-148. [CrossRef]

45. Baba, F.M.; Ge, H. Overheating risk of a single-family detached house built at different ages under current and future climate in Canada. In Proceedings of the 12th Nordic Symposium on Building Physics (NSB 2020), Tallinn, Estonia, 6-9 September 2020; EDP Sciences: Les Ulis, France, 2020; Volume 172, p. 02004.

46. Sehizadeh, A.; Ge, H. Impact of Future Climate Change on the Overheating of Canadian Housing Retrofitted to the PassiveHaus Standard: A case study. In Proceedings of the eSim 2014, Ottawa, ON, Canada, 8-9 May 2014. Available online: https://spectrum.library.concordia.ca/980602/ (accessed on 28 November 2020).

47. Lamrhari, E.-H.D.; Benhamou, B. Thermal behavior and energy saving analysis of a flat with different energy efficiency measures in six climates. Build. Simul. 2018, 11, 1123-1144. [CrossRef]

48. Van Hooff, T.; Blocken, B.B.; Hensen, J.J.; Timmermans, H. On the predicted effectiveness of climate adaptation measures for residential buildings. Build. Environ. 2014, 82, 300-316. [CrossRef]

49. Makantasi, A.-M.; Mavrogianni, A. Adaptation of London's social housing to climate change through retrofit: A holistic evaluation approach. Adv. Build. Energy Res. 2015, 10, 99-124. [CrossRef]

Publisher's Note: MDPI stays neutral with regard to jurisdictional claims in published maps and institutional affiliations. 